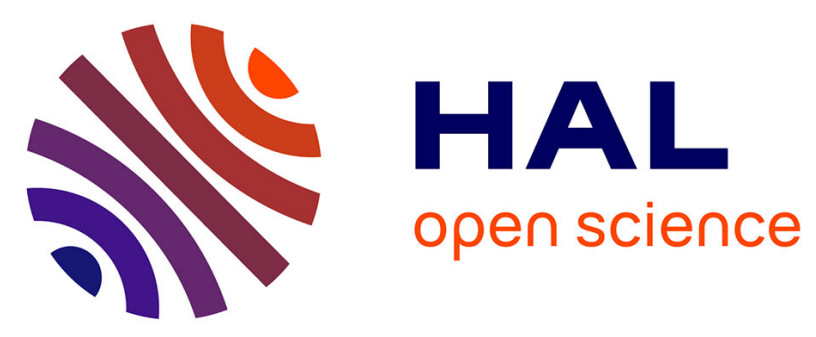

\title{
Copper Coordination to Water and Ammonia in Cu II -Exchanged SSZ-13: Atomistic Insights from DFT Calculations and in Situ XAS Experiments
}

B. Kerkeni, D. Berthout, Dorothée Berthomieu, D. Doronkin, M. Casapu, J.-D. Grunwaldt, C. Chizallet

\section{To cite this version:}

B. Kerkeni, D. Berthout, Dorothée Berthomieu, D. Doronkin, M. Casapu, et al.. Copper Coordination to Water and Ammonia in Cu II -Exchanged SSZ-13: Atomistic Insights from DFT Calculations and in Situ XAS Experiments. Journal of Physical Chemistry C, 2018, 122 (29), pp.16741 - 16755. 10.1021/acs.jpcc.8b03572 . hal-01863890

\section{HAL Id: hal-01863890 \\ https://hal.umontpellier.fr/hal-01863890}

Submitted on 8 Nov 2018

HAL is a multi-disciplinary open access archive for the deposit and dissemination of scientific research documents, whether they are published or not. The documents may come from teaching and research institutions in France or abroad, or from public or private research centers.
L'archive ouverte pluridisciplinaire HAL, est destinée au dépôt et à la diffusion de documents scientifiques de niveau recherche, publiés ou non, émanant des établissements d'enseignement et de recherche français ou étrangers, des laboratoires publics ou privés. 


\title{
Copper Coordination to Water and Ammonia
}

\author{
in $\mathrm{Cu}^{\mathrm{II}}$-Exchanged SSZ-13:
}

\section{Atomistic Insights from DFT Calculations}

\section{and In Situ XAS Experiments}

B. Kerkeni, ${ }^{1,2,3}$ D. Berthout, ${ }^{1}$ D. Berthomieu, ${ }^{4}$ D. E. Doronkin, ${ }^{5,6^{*}}$ M. Casapu, ${ }^{5}$ J.-D. Grunwaldt, ${ }^{5,6}$ C. Chizallet ${ }^{1, *}$

${ }^{1}$ IFP Energies Nouvelles, Rond-point de l'échangeur de Solaize, BP3, 69360 Solaize, France ; Institut Carnot IFPEN Transports Energie

${ }^{2}$ Faculté des Sciences de Tunis, Laboratoire Physique de la Matière Condensée, 2092 Université Tunis El Manar, Tunisia

${ }^{3}$ Université de la Manouba, Institut Supérieur des Arts Multimédia de la Manouba, 2010, la Manouba, Tunisia

${ }^{4}$ Institut Charles Gerhardt Montpellier, UMR 5253 CNRS-ENSCM-UM, Montpellier, France

${ }^{5}$ Institute for Chemical Technology and Polymer Chemistry, Karlsruhe Institute of Technology, 76131

Karlsruhe, Germany

${ }^{6}$ Institute of Catalysis Research and Technology, Karlsruhe Institute of Technology, 76344 Eggenstein-Leopoldshafen, Germany

Corresponding authors : celine.chizallet@ifpen.fr, $\underline{\text { dmitry.doronkin@ @it.edu }}$ 


\section{ABSTRACT:}

In this study the coordination sphere of copper in $\mathrm{Cu}-\mathrm{SSZ}-13$ as catalyst for the selective catalytic reduction (SCR) of $\mathrm{NO}_{\mathrm{x}}$ by ammonia is analyzed as a function of the environmental parameters: temperature, partial pressure of water $\mathrm{P}\left(\mathrm{H}_{2} \mathrm{O}\right)$ and partial pressure of ammonia $\mathrm{P}\left(\mathrm{NH}_{3}\right)$. By periodic Density Functional Theory (DFT) calculations, we obtain stability domains for variable loadings of water and ammonia $\left(\mathrm{nH}_{2} \mathrm{O}+\mathrm{mNH}_{3}\right.$ with $\left.(\mathrm{m}+\mathrm{n} \leq 6)\right)$ close to $\mathrm{Cu}^{\mathrm{II}}$ ions, which are located at $6 \mathrm{MR}$ or $8 \mathrm{MR}$ of the zeolitic structure. Ab initio calculations and thermodynamic investigations were performed to build phase diagrams, with vibrational analysis, so as to provide Gibbs free energy $\mathrm{G}$ values. Copper located in the 8MR appears to be more reactive towards $\mathrm{H}_{2} \mathrm{O}$ and $\mathrm{NH}_{3}$ adsorption than the one in the $6 \mathrm{MR}$, due to a lower coordination number of copper at $8 \mathrm{MR}$ in the absence of adsorbates. Depending on the operating conditions, structures containing adsorbed water and ammonia as ligands at the metal site can simultaneously be stabilized. The most widespread coordination number of $\mathrm{Cu}^{\mathrm{II}}$ is 4 even at $m+n>4$. The theoretical predictions were validated by in situ XAS, in two gas atmospheres: dry He with $\mathrm{P}\left(\mathrm{NH}_{3}\right)=10^{-3}$ bar $(1000 \mathrm{ppm})$, as well as He with $\mathrm{P}\left(\mathrm{NH}_{3}\right)=10^{-3}$ bar and $\mathrm{P}\left(\mathrm{H}_{2} \mathrm{O}\right)=10^{-2}$ bar. Trends in terms of ammonia desorption temperature as well as coordination numbers are well reproduced. Experimentally determined behaviors of $\mathrm{Cu}^{\mathrm{I}}$ and $\mathrm{Cu}^{\mathrm{II}}$ open new perspectives for the systematic computational investigation of the behavior of $\mathrm{Cu}^{\mathrm{I}}$ in $\mathrm{H}_{2} \mathrm{O} / \mathrm{NH}_{3}$ atmosphere. 


\section{INTRODUCTION}

The emission of nitrogen oxides (NOx) into the earth's atmosphere, produced through the combustion of fossil fuels, is a major concern for today's society. ${ }^{1}$ As a result, stricter legislation requires removal of most of NOx emitted from artificial sources. Diesel engine after-treatment systems for passenger cars have to face several challenges regarding the level of emitted nitrogen oxides (NOx) required for the current and upcoming emission regulations (California LEV III, US EPA Tier 3, Euro 6c/6d and Real Driving Emissions legislation) as well as too high NOx concentration levels in certain urban areas. This has led researchers to design and develop new catalysts with a wide temperature range of activity and high selectivity towards $\mathrm{N}_{2}$. In particular, Selective Catalytic Reduction with ammonia $\left(\mathrm{NH}_{3}-\mathrm{SCR}\right)$ has emerged as an efficient technology to remove environmentally harmful nitrogen oxides (NOx, $x=1,2$ ) from oxygen-rich exhausts, typical of diesel engines, to levels required by emission regulations. ${ }^{2-4} \mathrm{NH}_{3}$ involved in the SCR process is typically generated via decomposition of aqueous urea solution, and produces $\mathrm{N}_{2}$ and $\mathrm{H}_{2} \mathrm{O}$ upon reaction with $\mathrm{NO}_{\mathrm{x}}$.

Copper-exchanged zeolites and zeotypes are widely used catalysts for NOx removal from mobile sources via $\mathrm{NH}_{3}$-SCR, and have been studied in numerous works. ${ }^{2-20} \mathrm{Cu}-\mathrm{SSZ}-13$ catalysts (framework type CHA) have been found to be one of the most active and selective materials in $\mathrm{NH}_{3}-\mathrm{SCR},{ }^{4,21-22}$ less prone to deactivation by hydrocarbon inhibition or thermal degradation than other metal-exchanged zeolites. ${ }^{3,14}$ They show exceptional activity for the $\mathrm{NH}_{3}$-SCR in the emission control systems of diesel vehicles, and are now in commercial use. $^{23}$

The CHA framework contains interconnected 6-, and 8-membered rings (6MR, 8MR) and relatively small pore radius $(\sim 3.8 \AA)$ in an $8 \mathrm{MR} .{ }^{24}$ Depending on the preparation conditions, ${ }^{15} \mathrm{Cu}-\mathrm{SSZ}-13$ exhibits different catalytic activity. Typical Si/Al 10 and $\mathrm{Cu} / \mathrm{Al} \sim 0.3^{25}$ are reported for $\mathrm{Cu}-\mathrm{SSZ}-13$ materials used in the $\mathrm{NH}_{3}$-SCR, both to ensure 
hydrothermal stability and to reduce copper species clustering. ${ }^{3}$ According to the literature, the valence state of copper active sites under ambient conditions is $+\mathrm{II}^{15}$ These sites were reported to be present as isolated $\mathrm{Cu}^{\mathrm{II}}$ and $\mathrm{Cu}^{\mathrm{II}}-\mathrm{OH}$ (depending on the hydration conditions $)^{15,26}$ with a preferential location in the plane of the $6 \mathrm{MR}$, according to several spectroscopic studies employing X-ray diffraction (XRD), X-ray absorption (XAS), and UVVis spectroscopy. ${ }^{3,27-31}$

However, X-ray based techniques and Density Functional Theory (DFT) calculations provide contrasted results, with copper located not only in $6 \mathrm{MR}^{27}$ but also in $8 \mathrm{MR}$ units of the SSZ-13 matrix. ${ }^{16,18-20}$ Finally, it was proposed that monomeric and / or dimeric $\mathrm{Cu}^{\mathrm{II}}$ are the active species in the SCR of NOx with ammonia on Cu-SSZ-13 catalysts. ${ }^{4,32}$ It was recently demonstrated that the formation of dimeric $\mathrm{Cu}^{\mathrm{II}}$ sites result from copper mobility occurring during the SCR with the ammonia addition process. ${ }^{17}$ From DFT calculations using cluster models and periodic models, mobility of copper in its reduced $\mathrm{Cu}^{\mathrm{I}}$ exchanged zeolite valence state in the presence of $\mathrm{NH}_{3}$ or $\mathrm{H}_{2} \mathrm{O}$ is predicted. ${ }^{17,33}$

Despite significant efforts in the past decade, in particular in terms of operando catalysts characterization, $3,5,16-17,19-20,34-35$ the relationships between zeolite composition, reaction conditions and active site location, as well as some aspects of the proposed SCR reaction mechanisms remain to be elucidated. ${ }^{3}$ The first aspect to be unraveled in this context is the structure of copper during SCR reactions. Ammonia as well as water are present in the SCR gas mixture at various partial pressures. The oxidative (due to the presence of water and $\mathrm{O}_{2}$ ) or reductive (due to the presence of ammonia or hydrocarbons) nature of the atmosphere, depending on the operating conditions, also influences the oxidation degree of copper $(+\mathrm{I}$ or + II). ${ }^{5,36-37}$

Since the late 90's (first with small clusters, then with periodic models), DFT based calculations were brought to determine copper active site structures in metal cation-exchanged 
zeolites, and recently for copper-exchanged chabazite., ${ }^{4,16-17,23,34,38-51}$ A large set of studies concluded (or assumed) the better stability of $\mathrm{Cu}^{\mathrm{II}}$ located at the $6 \mathrm{MR}$, with respect to $8 \mathrm{MR}$, in the absence of adsorbates. ${ }^{34,42-44}$

X-ray absorption spectroscopy (XAS) is ideally suited to study transition metal based catalysts under realistic or operating conditions (gas composition, temperature, pressure etc.) due to high penetrating power of X-rays which allows using sophisticated in situ cells. ${ }^{52} \mathrm{X}$-ray absorption near edge structure (XANES) is sensitive to oxidation state and coordination environment (coordination numbers, nature of neighboring atoms, and coordination geometry), while extended X-ray absorption fine structure (EXAFS) allows assigning coordination number and distance to nearest neighbor atoms as well as approximating their atomic numbers. XAS, unlike X-ray diffraction, can be applied to study systems without longrange order and is one of the techniques of choice to characterize $\mathrm{Cu}$ sites in zeolite catalysts. Previous studies have shown that $\mathrm{Cu}$ species in $\mathrm{Cu}-\mathrm{SSZ}-13$ zeolites are very mobile and can be located at $8 \mathrm{MR},{ }^{32} 6 \mathrm{MR}^{36}$ or both at the same time, ${ }^{16}$ while coordination numbers vary between 5 and 2 depending on temperature and gas atmosphere ${ }^{36,53}$ with the most strongly coordinating ligands being $\mathrm{NH}_{3}$ and $\mathrm{H}_{2} \mathrm{O} .{ }^{35}$ Efficient application of $\mathrm{Cu}-\mathrm{SSZ}-13$ catalysts for NOx removal from mobile sources requires precise $\mathrm{NH}_{3}$ dosage which, in turn, is possible only if the amount of $\mathrm{NH}_{3}$ interacting with $\mathrm{Cu}$ sites is known. Previously, XANES spectroscopy demonstrated rapid changes in the coordination sphere of $\mathrm{Cu}$-zeolite automotive catalysts during driving cycles ${ }^{53}$ but the comprehensive mapping of the structure of $\mathrm{Cu}$-sites under realistic conditions has not been performed so far.

The aim of the present study is to investigate the possible adsorption sites, to identify the most stable structures during experimental conditions and to quantify the capacity of $\mathrm{Cu}$ centers to adsorb variable loads of gaseous water and ammonia $\left(\mathrm{nH}_{2} \mathrm{O}+\mathrm{mNH}_{3}\right.$ with $(\mathrm{m}+\mathrm{n} \leq$ 6)). The present study considers the isolated $\mathrm{Cu}^{\mathrm{II}}$ ions exchanged-SSZ-13 as the active site. In 
our computational modeling we included the two principal locations $6 \mathrm{MR}$ and $8 \mathrm{MR}$ for the $\mathrm{Cu}$ ions in the $\mathrm{CHA}$ framework in order to determine coordination numbers in combination with stability domains. The predictions are benchmarked against results obtained by in situ XAS performed on a Cu-SSZ-13 catalyst under reaction conditions relevant for the real-world applications and comparable to the ones studied by DFT. We consider these investigations as a first step to be tackled prior to deriving catalytic reaction mechanisms.

\section{Experimental and methods}

\subsection{DFT calculations}

Periodic Density Functional Theory (DFT) calculations were performed using a planewave method as implemented in the Vienna Ab initio Simulation Package (version 5.4.1). ${ }^{54-55}$ The exchange-correlation functional was treated within the generalized gradient approximation (GGA) parameterized by Perdew, Burke and Ernzerhof ${ }^{56}$ (PBE) and the electron-ion interaction was described by the projector augmented wave (PAW) scheme. ${ }^{57}$ Van der Waals corrections as proposed within the Grimme formalism (D2) were applied. ${ }^{58}$ We also carried out test calculations with the opt-PBE ${ }^{59}$ non-local exchange-correlation functional, with deviation on adsorption energies between 5 and $20 \mathrm{~kJ} \cdot \mathrm{mol}^{-1}$ with respect to PBE-D2. Note also that Göltl et al. ${ }^{46}$ showed that for water adsorption issues, the choice of PBE versus a hybrid functional (HSE06 in their case) has no significant effect on the thermodynamic diagrams, whereas the introduction of dispersion corrections has a significant effect. For these reasons, we chose to perform routine calculations at the PBE-D2 level.

The energy cutoff was set to $800 \mathrm{eV}$ for the initial lattice parameters optimizations, then to $400 \mathrm{eV}$ for all other investigations. A $1 \times 2 \times 2 \mathrm{k}$-point mesh was employed for the double rhombohedral cell modeled (see below). Gaussian smearing with $\sigma=0.02 \mathrm{eV}$ was used. Spinpolarized calculations were performed. The criterion for the convergence of the self- 
consistent cycles was set to $10^{-5} \mathrm{eV}$. Bader charges ${ }^{60-61}$ were calculated at the same level of theory. Geometry optimizations were run until forces on relaxed atoms were lower than $2.10^{-2}$ $\mathrm{eV} \cdot \AA^{-1}$

The initial cell and atomic positions were taken from the International Zeolite Association database (CHA framework). ${ }^{62} \mathrm{We}$ constructed a double cell (with respect to the primitive one, containing 73 atoms) by doubling the $a$ cell parameter, so as to keep a rather high $\mathrm{Si} / \mathrm{Al}=11$ while exchanging two aluminum atoms per double cell, and adding one copper atom per double cell $(\mathrm{Cu} / \mathrm{Al}=0.5)$, so that copper is initially in +2 oxidation state. $\mathrm{Cu}^{\mathrm{II}}$ species can also be modeled by a cell where only aluminum per copper exists, but compensating the charge by an extra $\mathrm{HO}^{-}$ion coordinated to copper $\left(\mathrm{Cu}^{\mathrm{II}}-\mathrm{OH}\right.$ species). The latter species were characterized by Borfecchia et al. ${ }^{16}$ For $\mathrm{Si} / \mathrm{Al}$ and $\mathrm{Cu} / \mathrm{Al}$ such as the one involved in the experimental part of our study (see section 2.2.), equal amounts of $\mathrm{Cu}^{\mathrm{II}}$ and $\mathrm{Cu}^{\mathrm{II}}-\mathrm{OH}$ are expected. ${ }^{43}$ Focusing on water or ammonia independent adsorptions at the 6MR site, Paolucci et al. compared the behavior of $\mathrm{Cu}^{\mathrm{II}}$ and $\mathrm{Cu}^{\mathrm{II}}-\mathrm{OH}$ (called $\left[\mathrm{Z}_{2} \mathrm{Cu}^{\mathrm{II}}\right]$ and $\left[\mathrm{ZCu}^{\mathrm{II}} \mathrm{OH}\right]$ in their study) and found similar behaviors in terms of cation mobility. Similar trends in adsorption energies were also observed. Hence, for the co-adsorption investigation, which requires the calculation of many more species, we restricted ourselves to the $\mathrm{Cu}^{\mathrm{II}}$ case. Moreover, Paolucci et al. ${ }^{43}$ demonstrated that $\mathrm{Cu}^{\mathrm{I}}$ nearly does not appear in the $6 \mathrm{MR}$ stability diagram in the water rich conditions, hence, $\mathrm{Cu}^{\mathrm{I}}$ systems were omitted to simplify calculations. We sampled several aluminum and copper locations (see section 3.1). To improve the sampling of stable configurations for water and/or ammonia adsorption, we performed short simulated annealing runs, based on first-principles NVT (constant number of atoms, volume and temperature) velocity scaled molecular dynamics at $673 \mathrm{~K}\left(400^{\circ} \mathrm{C}\right)$, followed by quenches at $0 \mathrm{~K}$ (with the same parameters as other geometry optimizations). The time for each step was set to $1 \mathrm{fs}$, for 
a total run of $1-5$ ps. Such an approach proved to be efficient for structure sampling of several kinds of systems. ${ }^{63-64}$

For the most stable optimized structures for a given stoichiometry ( $\mathrm{n}$ adsorbed water molecules and $\mathrm{m}$ adsorbed ammonia molecules), and for a given initial configuration (copper in $6 \mathrm{MR}$ or $8 \mathrm{MR})$, the cumulated adsorption energy $\Delta_{\mathrm{ads}} \mathrm{U}_{(\mathrm{n}, \mathrm{m})}$ is given by equation 1 , function of the energy of the zeolitic cells $U_{\text {zeo(n,m) }}$ containing $n$ water molecules and $m$ ammonia molecules, $U_{\text {water }}$ and $U_{\text {ammonia }}$ being the energies of the isolated water and ammonia molecules, respectively.

$$
\Delta_{\mathrm{ads}} \mathrm{U}_{(\mathrm{n}, \mathrm{m})}=\mathrm{U}_{\mathrm{zeo}(\mathrm{n}, \mathrm{m})}-\mathrm{U}_{\mathrm{zeo}(0,0)}-\mathrm{n} \mathrm{U}_{\text {water }}-\mathrm{m} \mathrm{U}_{\text {ammonia }}
$$

Equation 1

For each of these species, the Gibbs free energy was calculated according to the approach

detailed in ref. ${ }^{65-66}$ by considering the rotational, translational, and vibrational degrees of freedom for gas-phase water and ammonia, and the vibrational degrees of freedom only for the zeolite models. Harmonic frequency calculations were performed on the optimized structures with the lowest energy values, using a finite-difference approximation, with a displacement of $\pm 0.02 \AA$ around the equilibrium atomic positions. All atoms within the zeolite cell were then allowed to relax. These calculations lead to the evaluation of the Gibbs free energy of adsorption $\Delta_{\mathrm{ads}} \mathrm{G}_{(\mathrm{n}, \mathrm{m})}$.

\subsection{Catalyst synthesis}

$\mathrm{Cu}-\mathrm{SSZ}-13$ zeolite $(\mathrm{Si}: \mathrm{Al}=16: 1, \mathrm{Cu}: \mathrm{Al}=1: 5,1.2 \mathrm{wt} . \% \mathrm{Cu})$ was prepared via hydrothermal synthesis reported earlier. ${ }^{35}$ First, 0.67 g sodium hydroxide, $41.1 \mathrm{~g}$ deionised water, $14.8 \mathrm{~g}$ N,N,N-trimethyladamantylammonium hydroxide (TMAdOH, 25 wt.\%, Sachem) and $0.43 \mathrm{~g}$ aluminium hydroxide were mixed together and stirred for $30 \mathrm{~min}$. Then $13.0 \mathrm{~g}$ colloidal silica (Ludox ${ }^{\circledR}$ AS-40) was added to the mixture and for stirred for another $10 \mathrm{~min}$. The as prepared gel was transferred into a $200 \mathrm{~mL}$ Teflon-lined autoclave and aged at room temperature for 2 
$\mathrm{h}$ after that it was heated statically for 4 days at $160{ }^{\circ} \mathrm{C}$. Next the autoclave was cooled down and depressurized, the resulting slurry was filtered, washed with $1 \mathrm{~L}$ deionised water, dried at $80{ }^{\circ} \mathrm{C}$ and calcined at $550{ }^{\circ} \mathrm{C}$ for $2 \mathrm{~h}$. The as prepared Na-SSZ-13 was ion exchanged with aqueous $1 \mathrm{M} \mathrm{NH}_{4} \mathrm{NO}_{3}$ solution $\left(20 \mathrm{~mL} / \mathrm{g}\right.$ zeolite) for $2 \mathrm{~h}$ at $75{ }^{\circ} \mathrm{C}$, washed with deionised water, dried at $80{ }^{\circ} \mathrm{C}$ and calcined at $550{ }^{\circ} \mathrm{C}$ for $2 \mathrm{~h}$. These steps were repeated for further two times without calcination at the final step to receive $\mathrm{NH}_{4}-\mathrm{SSZ}-13 . \mathrm{Cu}^{\mathrm{II}}$ was introduced by liquid ion exchange with $0.005 \mathrm{M} \mathrm{Cu}(\mathrm{OAc})_{2}$ aqueous solution $(100 \mathrm{~mL} / \mathrm{g}$ zeolite $)$ at room temperature for $24 \mathrm{~h}$. The resulting material was filtered, washed with $1 \mathrm{~L}$ deionised water, dried at $80{ }^{\circ} \mathrm{C}$ and calcined at $550{ }^{\circ} \mathrm{C}$ for $8 \mathrm{~h}$.

\subsection{X-ray absorption spectroscopic studies}

In situ XAS measurements around the $\mathrm{Cu} \mathrm{K}$ edge $(8979 \mathrm{eV})$ were performed at the SuperXAS beamline (SLS, Villigen, Switzerland) using a fast oscillating Si (111) channel-cut monochromator. ${ }^{67}$ Quick XAS (QEXAFS) spectra were measured at a frequency of $10 \mathrm{~Hz}$, all spectra collected in 1 minute were aligned and averaged for further analysis. A setup for transmission XAS with a heated quartz capillary microreactor (plug flow geometry, diameter $1.5 \mathrm{~mm}$, wall thickness $0.02 \mathrm{~mm}$, heated with an air blower, beam size of about $0.2 \times 0.2$

$\mathrm{mm}^{2}$, monitoring middle of the catalyst bed) was used. ${ }^{52} 6.2 \mathrm{mg}$ of Cu-SSZ-13 (sieve fraction 0.1-0.2 mm, supported by two quartz wool plugs) was used, which resulted in $7 \mathrm{~mm}$ bed length. Prior to the measurements the catalyst was pretreated (dehydrated) in a flow of $10 \% \mathrm{O}_{2}$ in $\mathrm{He}$ (rest $\mathrm{H}_{2} \mathrm{O}$ content in the gas mixture 5-10 ppm, $\mathrm{P}\left(\mathrm{H}_{2} \mathrm{O}\right) \sim 10^{-5}$ bar) at $823 \mathrm{~K}(10 \mathrm{~K} / \mathrm{min}$ ramp rate, $10 \mathrm{~min}$ dwell time at $823 \mathrm{~K}$ ) and cooled to room temperature in the same gas mixture. The dehydration experiment was monitored by QEXAFS. For the in situ measurements with $\mathrm{NH}_{3}$ the catalyst was heated from $313 \mathrm{~K}$ to $823 \mathrm{~K}(10 \mathrm{~K} / \mathrm{min}$ ramp rate) in two gas atmospheres: dry He with $\mathrm{P}\left(\mathrm{NH}_{3}\right)=10^{-3}$ bar $(1000 \mathrm{ppm})$, as well as $\mathrm{He}$ with 
$\mathrm{P}\left(\mathrm{NH}_{3}\right)=10^{-3}$ bar and approx. $\mathrm{P}\left(\mathrm{H}_{2} \mathrm{O}\right)=10^{-2}$ bar $\left(1000\right.$ ppm NH 3 and approx. $\left.1 \% \mathrm{H}_{2} \mathrm{O}\right)$. The gas flow through the catalyst was $50 \mathrm{~mL} / \mathrm{min}$ which results in a Gas Hourly Space Velocity (GHSV) of approx. $200000 \mathrm{~h}^{-1}$. Gases were dosed via mass flow controllers, whereas water was fed via a saturator. The gas composition was monitored by an MKS MultiGas 2030 FTIR analyser.

The amount of $\mathrm{Cu}^{\mathrm{II}}, \mathrm{Cu}^{\mathrm{I}} \cdot \mathrm{xNH}_{3}$, and $\mathrm{Cu}^{\mathrm{I}}$ was determined via linear combination analysis (LCA) of XANES spectra between $8976 \mathrm{eV}$ and $9004 \mathrm{eV}$ using ATHENA software from the IFFEFIT package. ${ }^{68}$ As references representing $\mathrm{Cu}^{\mathrm{II}}$ species a set of $\mathrm{Cu}-\mathrm{SSZ}-13$ spectra obtained in 1000 ppm NO, $10 \% \mathrm{O}_{2}, 1 \% \mathrm{H}_{2} \mathrm{O}$ at $343,473,623$, and $773 \mathrm{~K}$ were used to account for changes of the shape of $\mathrm{Cu}^{\mathrm{II}}$ XANES spectra with coordination number and geometry ${ }^{53}$. Previously, spectra measured under $\mathrm{NO}$ and $\mathrm{O}_{2}$ at different temperatures were attributed to $\mathrm{Cu}^{\mathrm{II}}$ species using High Energy Resolution Fluorescence Detected (HERFD) XANES and X-ray Emission Spectroscopy (XES). ${ }^{20,35}$ Two other reference spectra for $\mathrm{Cu}^{\mathrm{I}} \cdot \mathrm{xNH}_{3}$ and $\mathrm{Cu}^{\mathrm{I}}$ species with and without ammonia in the coordination sphere, were extracted from the experimental dataset measured at $\mathrm{P}\left(\mathrm{NH}_{3}\right)=10^{-3}$ bar using Multivariate Curve Resolution - Alternating Least Squares method (MCR-ALS). ${ }^{69-70}$ This mathematical procedure used in chemometrics allows extraction of a priori unknown reference spectra from a set of spectra of mixtures with changing concentrations. Non-negativity constraint was applied to the matrix of reference spectra and unimodality constraint was applied to concentration profiles. The obtained reference spectra indeed demonstrated all the features of $\mathrm{Cu}^{\mathrm{I}}$ with and without directly adsorbed ammonia as previously described in refs. ${ }^{16,35}$ and were assigned correspondingly. MCR-ALS was required because high energy resolution data available in the literature cannot be used for fitting conventional XANES spectra due to differences in spectral resolution (the comparison between the used $\mathrm{Cu}^{\mathrm{I}} \cdot \mathrm{xNH}_{3}$ and $\mathrm{Cu}^{\mathrm{I}}$ reference spectra and the previously attributed HERFD-XANES spectra is available in the 
Supporting Information S1). Furthermore, the strategy of using the catalyst sample in question to obtain reference XANES spectra allows obtaining the best fits as was demonstrated by Lamberti et al. $^{71}$

The total coordination number in the first shell around $\mathrm{Cu}$ sites (sum of $\mathrm{N}+\mathrm{O}$ neighbors) was estimated by analysis of EXAFS spectra. EXAFS spectra were background subtracted, normalized, $k^{1}$-, $k^{2}$-, and $k^{3}$-weighted and Fourier transformed in the $k$ range $2-10 \AA^{-1}$ using ATHENA. Finally, fitting in R-space was performed using ARTEMIS ${ }^{68} \mathrm{E}_{0}$ was selected at $8989 \mathrm{eV}$ at a normalized absorbance of 0.5 , and not taking into account the shoulder at 8983 $\mathrm{eV}$ related to different $\mathrm{Cu}^{\mathrm{I}}$ species. Theoretical backscattering amplitudes and phases were calculated by FEFF $6.0^{72}$ and adjusted to the experimental spectra by a least square method in R-space between 1 and $1.9 \AA$ (corresponding to the first $\mathrm{Cu}-\mathrm{O} / \mathrm{N}$ shell). From the fit of a reference $\mathrm{CuO}$ spectrum amplitude reduction factor $\mathrm{S}_{0}^{2}=0.8$ was obtained and then the coordination numbers, interatomic distances, energy shift $\left(\delta \mathrm{E}_{0}\right)$ and mean square deviation of interatomic distances $\left(\sigma^{2}\right)$ were refined. The absolute misfit between theory and experiment was expressed by $\rho$.

\section{RESULTS AND DISCUSSION}

\subsection{Models for $\mathrm{Cu}^{2+}$ exchanged SSZ-13}

In the present work, we choose to simulate $\mathrm{Cu}-\mathrm{SSZ}-13$ by cells containing only $\mathrm{Cu}^{\mathrm{II}}$ as charge-compensating cations, thus, with a constant $\mathrm{Cu} / \mathrm{Al}$ ratio of 0.5 . Several positions of aluminum and copper were investigated, with results provided in Supporting Information S2. Two configurations were selected for copper in $6 \mathrm{MR}$ and $8 \mathrm{MR}$, being the most stable configurations found for each MR (Figure 1). In the following, regarding the computational results, copper-ligand distances higher than $2.3 \AA$ are not considered in the numbering of the bonds in which $\mathrm{Cu}^{\mathrm{II}}$ is involved. 
For copper in the 6MR, a distorted planar square environment was found (Figure 1-(a)), in agreement with previous computational findings, ${ }^{43-44}$ with the two aluminum in diametrically opposed positions within the same 6MR. For copper in $8 \mathrm{MR}$, the most favorable configuration is found if aluminum substitutes second neighbors in terms of $\mathrm{T}$ sites. The copper ion is then three-fold coordinated, which is likely the origin of an enhanced reactivity, as it will be shown in the following. The most stable configuration corresponds to copper at $6 \mathrm{MR}$, with an energy difference of $97 \mathrm{~kJ} \cdot \mathrm{mol}^{-1}$ with respect to the selected configuration where copper is at the $8 \mathrm{MR}$, in agreement with many computational and experimental studies. $^{3,27-31,44}$ For a larger sampling of aluminum locations in the presence of water, the reader is referred to the work of Göltl et al. ${ }^{46}$ In the present work, we do not aim at probing all theoretically possible aluminum positions. We rather put our effort on the investigation of the adsorption of variable amount of water and/or ammonia on the two representative sites, sampling all possible combinations in terms of amount of water and / or ammonia in the coordination shell of copper.

(a)
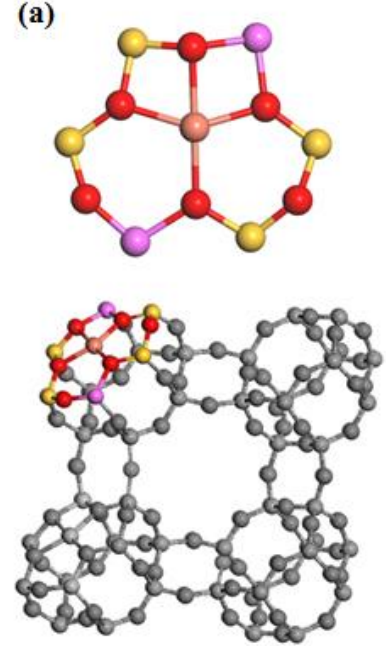

(b)
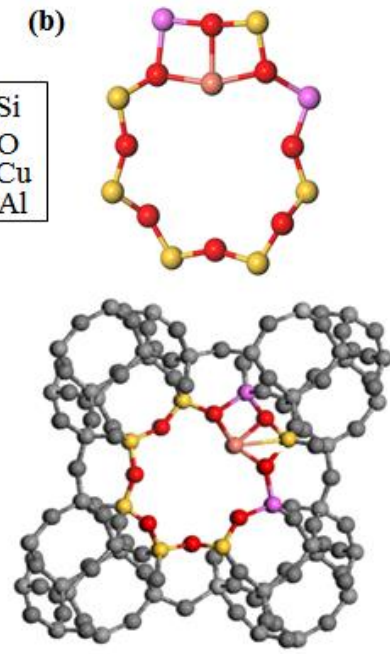

Figure 1. Models chosen to investigate reactivity of $\mathrm{Cu}^{\mathrm{II}}$ at $6 \mathrm{MR}$ (a) and $8 \mathrm{MR}$ (b). Top views of the rings and their location in the structure are shown. 


\subsection{Independent water or ammonia adsorption from DFT calculations}

Next, the coordination of $n$ water molecules $(1 \leq n \leq 6)$ or $m$ ammonia molecules $(1 \leq$ $\mathrm{m} \leq 6)$ to copper was investigated (the most stable structures are reported in the Supporting Information S3). Regarding the 6MR site, the first adsorbed water / ammonia molecule coordinates on top of the copper atom. The coordination number is increased to 5, whereas the position of the copper atom is shifted upward, above the plane of the 6MR. Higher (in absolute value) adsorption energy (Figure 2) is calculated for adsorption of ammonia than for water $\left(-127\right.$ and $-60 \mathrm{~kJ} \cdot \mathrm{mol}^{-1}$ respectively), in line with previous gas phase calculations. ${ }^{73}$ This trend is followed and becomes more pronounced upon the increase of the number of water or ammonia molecules coordinated to copper in 6MR. The orders of magnitude of adsorption energies for water and ammonia are in agreement with the literature. ${ }^{43}$ Starting from $n=6$ or $\mathrm{m}=3$, the copper ion is strongly shifted above the plane of the $6 \mathrm{MR}$ with final loss of coordination to the framework. The ligands are in fact coordinated to copper up to $\mathrm{n}$ or $\mathrm{m}=5$, the $6^{\text {th }}$ molecule is ejected from the coordination sphere in the course of the optimization and is linked by $\mathrm{H}$ bonds to the first shell.

Note that we tried to optimize dissociated form of the water molecule at the 6MR site, for the adsorption of one water molecule, and all calculations led to the reformation of the dissociated $\mathrm{O}-\mathrm{H}$ bond, and went back to a non-dissociated water molecule. We cannot exclude that such configurations can exist for other $(n, m)$ values however.

Regarding $\mathrm{Cu}^{\mathrm{II}}$ initially close to $8 \mathrm{MR}$, the adsorption energies are more negative than on the $6 \mathrm{MR}\left(-198\right.$ and $-241 \mathrm{~kJ} \cdot \mathrm{mol}^{-1}$ for water and ammonia on $8 \mathrm{MR}$, respectively), as expected from the lower initial coordination number of copper ( 3 instead of 4$). \mathrm{Cu}^{\mathrm{II}}$ then adopts a distorted square planar geometry, then the coordination number increases before disconnecting from the framework from $n=5$ or $m=4$. Again, the interaction with ammonia is stronger than with water. 
Bader charges on $\mathrm{Cu}^{\mathrm{II}}$ were calculated for each site and water/ammonia content (Figure 2-(b)). Without water nor ammonia, the charge of $\mathrm{Cu}^{\mathrm{II}}$ at the $8 \mathrm{MR}$ site is higher than at the $6 \mathrm{MR}$ site, and in both cases lower than two, consistent with the previous findings. ${ }^{74}$ This difference between the two sites is again likely due to the lower coordination number of copper at the $8 \mathrm{MR}$, leading to lower electronic density donated from the oxygen ligands. This strong difference is compensated right from the adsorption of the first ammonia molecule or the second water molecule. The charge is also higher in the presence of water rather than in the presence of ammonia, in line with previous results on the $6 \mathrm{MR}$ site. ${ }^{34}$ This may be related to the respective positions of $\mathrm{H}_{2} \mathrm{O}$ and $\mathrm{NH}_{3}$ in the spectrochemical series, with higher donor nature of ammonia with respect to water. Finally, increasing the water content leads to an increase of the charge, whereas increasing the ammonia content decreases it. In this way the framework oxygen can be localized in the spectrochemical series between water and ammonia. Note, however, that in all cases the Bader charge is substantially lower than +2 .

Considering the differences in stability of the $6 \mathrm{MR}$ system and the $8 \mathrm{MR}$ one without adsorbates, revised cumulated adsorption energies were calculated. For this purpose, $\mathrm{Cu}$ at 6MR (the most stable one) without adsorbates was taken as a reference point. This shifts the data up by $97 \mathrm{~kJ} \cdot \mathrm{mol}^{-1}$ for $8 \mathrm{MR}$ (Supporting Information S4). Adsorption makes the two systems to be closer in energy than the initial systems without adsorbates, the 8MR system even becoming the most stable for some compositions ( $n=3$ for example). This confirms that the initial energy difference was mainly due to the threefold coordinated nature of $\mathrm{Cu}^{\mathrm{II}}$ in $8 \mathrm{MR}$, which is increased to 4 as soon as it coordinates with the first water or ammonia ligand. This is also due to the fact that copper is dislodged from its exchange position for sufficiently high water or ammonia loading, rendering the considered systems quasi-equivalent. However, the two configurations need to be considered when copper is still attached to the framework. 
(a)

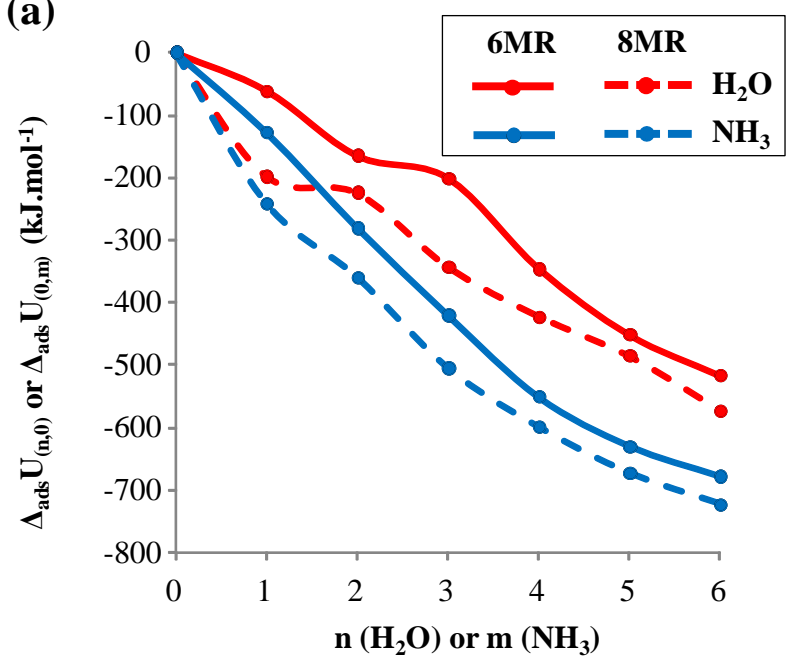

(b)

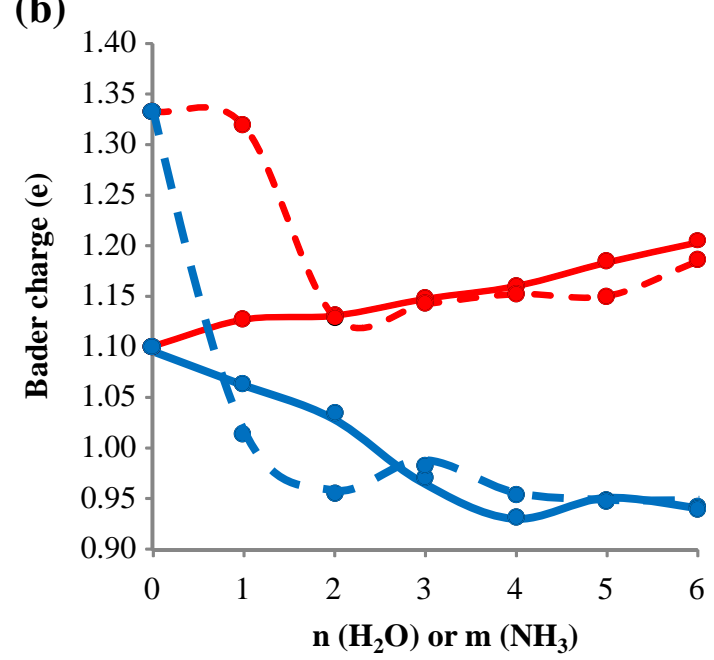

Figure 2. (a) Cumulated adsorption energies and (b) Bader charges at copper, for the adsorption of $\mathrm{H}_{2} \mathrm{O}$ (n molecules) or $\mathrm{NH}_{3}$ (m molecules) independently, close to copper located in the 6MR or 8MR, from DFT calculations. Lines serve as guides to the eye.

Based on the calculated free energies of each species, phase diagrams were constructed (Figure 3). They describe the nature of the most stable system as a function of the temperature and $\mathrm{P}\left(\mathrm{H}_{2} \mathrm{O}\right)$ or $\mathrm{P}\left(\mathrm{NH}_{3}\right)$. The investigated structures are called by $(\mathrm{n}, \mathrm{m}), \mathrm{n}$ being the number of water molecules, $m$ the number of ammonia molecules per $\mathrm{Cu}^{\mathrm{II}}$. The most stable structures at typical partial pressures $\left(\mathrm{P}\left(\mathrm{H}_{2} \mathrm{O}\right)=10^{-2}\right.$ bar, typical of the dehydration experiment, and $\mathrm{P}\left(\mathrm{H}_{2} \mathrm{O}\right)=10^{-2}$ bar and $\mathrm{P}\left(\mathrm{NH}_{3}\right)=10^{-3}$ bar $)$ are shown in Figure 4 as a function of the temperature. The chosen conditions correspond to the X-ray dehydration and absorption experiment reported in sections 3.4 and 3.5. Not all calculated stoichiometries exhibit stability domains on the diagrams. The higher reactivity of $\mathrm{Cu}^{\mathrm{II}}$ at $8 \mathrm{MR}$ towards $\mathrm{NH}_{3}$ and $\mathrm{H}_{2} \mathrm{O}$ adsorption is visible from the smaller stability domain of the structure without water and ammonia ligands $((0,0)$ structure, Figures $3-(b),(d))$ on the later site. The higher reactivity of ammonia with respect to water is also reflected by the smallest stability domain of the $(0,0)$ structure. For both molecules, the loss of the adsorbed ligands upon thermal treatment is 
expected to be more abrupt (transition from $(5,0)$ to $(0,0)$ for water at $\mathrm{P}\left(\mathrm{H}_{2} \mathrm{O}\right)<10^{-1}$ bar, from $(0,4)$ to $(0,0)$ for ammonia at $\mathrm{P}\left(\mathrm{NH}_{3}\right)<10^{-4}$ bar $)$ at the $6 \mathrm{MR}$ rather than on the $8 \mathrm{MR}$.

Note that the trends in the $\left(\mathrm{P}\left(\mathrm{H}_{2} \mathrm{O}\right)\right)$, $\left.\mathrm{T}\right)$ diagram for water adsorption in $6 \mathrm{MR}$ are comparable to the trends obtained by Göltl et al. ${ }^{46}$ and by Paolucci et al. ${ }^{43}$ In the latter work the authors did not consider $8 \mathrm{MR}$ sites, but solely $6 \mathrm{MR}$ sites with $\mathrm{Cu} / \mathrm{Cu}^{\mathrm{II}}$ species. It was shown that $\mathrm{Cu}^{\mathrm{I}}$ nearly does not appear in the diagram in the sampled water rich conditions ${ }^{43}$ confirming that omitting $\mathrm{Cu}^{\mathrm{I}}$ is not critical under these conditions.
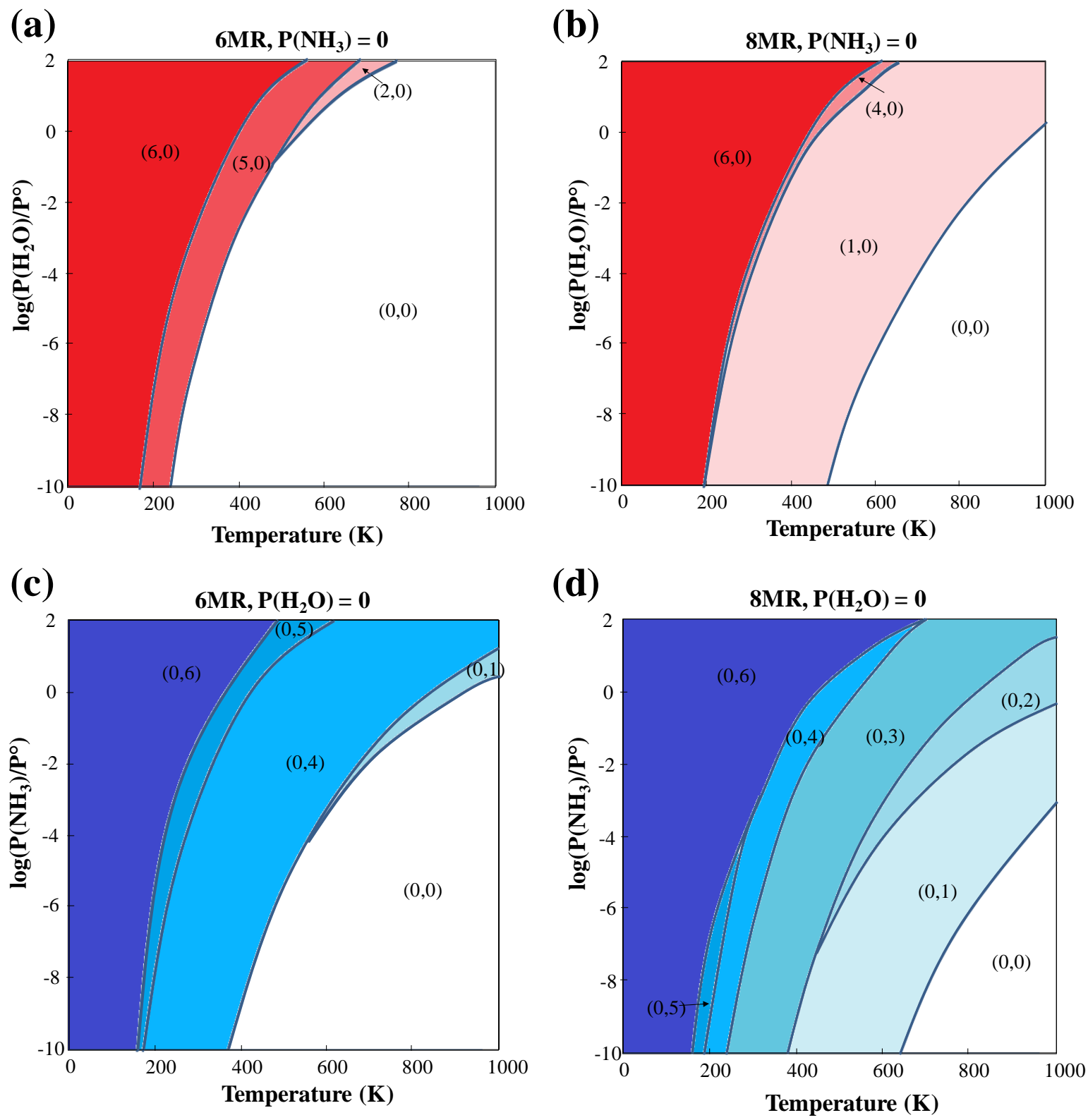
Figure 3. Phase diagrams from DFT calculations for (a) $\mathrm{H}_{2} \mathrm{O}$ adsorption at the $6 \mathrm{MR}$, (b) $\mathrm{H}_{2} \mathrm{O}$ adsorption at the $8 \mathrm{MR}$, (c) $\mathrm{NH}_{3}$ adsorption at the $6 \mathrm{MR}$, (d) $\mathrm{NH}_{3}$ adsorption at the $8 \mathrm{MR}$. The most stable systems in given conditions are called by $(\mathrm{n}, \mathrm{m}), \mathrm{n}$ being the number of water molecules, $\mathrm{m}$ the number of ammonia molecule per $\mathrm{Cu}^{\mathrm{II}}$.

In the conditions chosen for the representation of Figure 4, water initiates the dislodgment of copper from its exchange position for temperatures lower than about $340 \mathrm{~K}$ at the $6 \mathrm{MR}$ site, and below $300 \mathrm{~K}$ at the $8 \mathrm{MR}$ site. For ammonia, the dislodgment is more strongly dependent on the initial configuration of $\mathrm{Cu}^{\text {II }}$. For copper at the $6 \mathrm{MR}$, mobility is to be expected below $600 \mathrm{~K}$, but only below $400 \mathrm{~K}$ for $\mathrm{Cu}$ located at $8 \mathrm{MR}$. However, for the last case, pronounced distortion relative to the $8 \mathrm{MR}$ plane is maintained up to about $600 \mathrm{~K}$. 
(a)
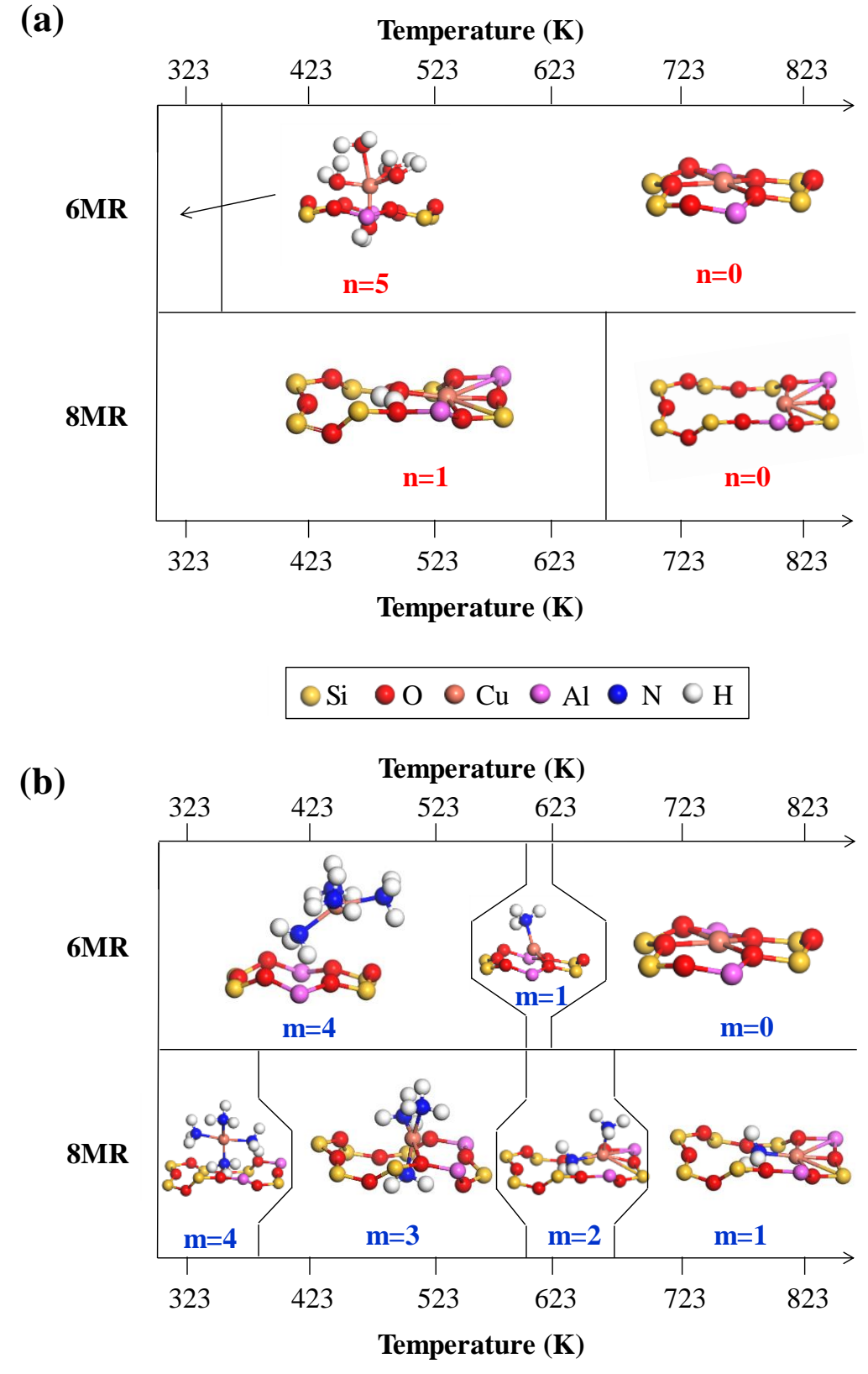

Figure 4. The most stable structures of $\mathrm{n}\left(\mathrm{H}_{2} \mathrm{O}\right)$ or $\mathrm{m}\left(\mathrm{NH}_{3}\right)$ adsorbed on $\mathrm{Cu}$-SSZ-13 calculated using DFT based methods, as a function of the temperature, for (a) $\mathrm{P}\left(\mathrm{H}_{2} \mathrm{O}\right)=10^{-5}$ bar, (b) $\mathrm{P}\left(\mathrm{NH}_{3}\right)=10^{-3}$ bar. (b) is also valid when water and ammonia are both present in the atmosphere, at $\mathrm{P}\left(\mathrm{H}_{2} \mathrm{O}\right)=10^{-2}$ bar and $\mathrm{P}\left(\mathrm{NH}_{3}\right)=10^{-3}$ bar. The conditions corresponding to (b) are the ones chosen for the experimental study.

The coordination numbers corresponding to the most stable structures found are reported in Figure 5 (coordination numbers and bond lengths are summarized in the Supporting Information S5). For the dehydration process (Figure 5-(a)), a two-step decrease of the 
coordination number is expected, first at the $6 \mathrm{MR}$ site (close to $340 \mathrm{~K}$, from 6 to 5 ) and then at the $8 \mathrm{MR}$ site (close to $660 \mathrm{~K}$, from 4 to 3). With ammonia in the feed (Figure 5-(b)), in the experimental operating conditions of interest (up to $823 \mathrm{~K}$ ), the total coordination number of $\mathrm{Cu}^{\mathrm{II}}$ is always 4 . At the lowest temperature, the coordination sphere is composed of nitrogen only, and a gradual nitrogen (from ammonia) exchange by oxygen (from the zeolitic framework) takes place during temperature increase, which induces ammonia desorption and re-coordination of copper to the framework site. Here again, a more abrupt transition from a nitrogen-rich to an oxygen-rich coordination sphere, is found for 6MR in comparison with 8MR. Under these environmental conditions, the sharpest transition takes place close to 600 K. 

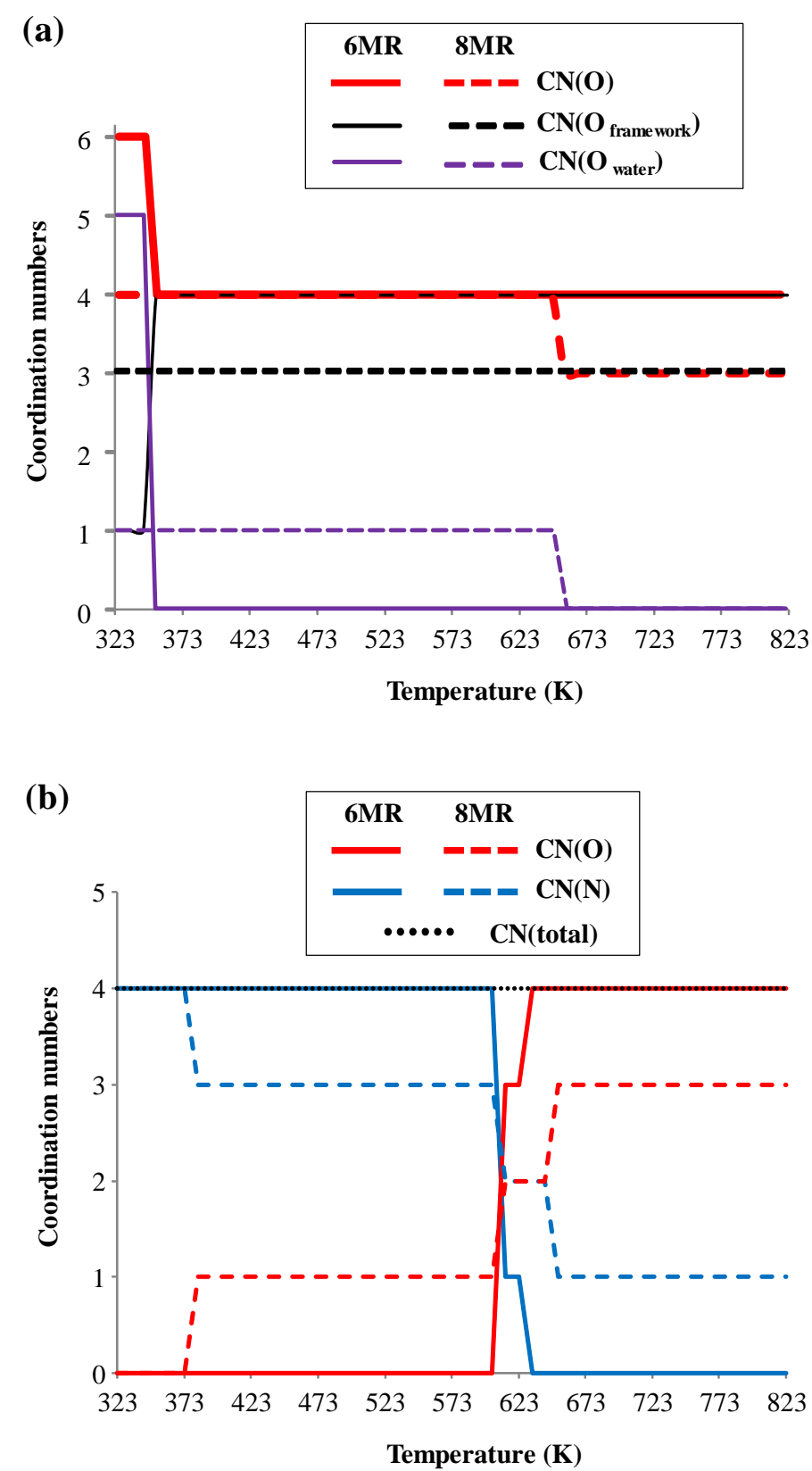

Figure 5. Coordination numbers $(\mathrm{CN})$ predicted from DFT calculations, as a function of the temperature, for (a) $\mathrm{P}\left(\mathrm{H}_{2} \mathrm{O}\right)=10^{-5}$ bar, (b) $\mathrm{P}\left(\mathrm{NH}_{3}\right)=10^{-3}$ bar (adsorption of ammonia alone), or for $\mathrm{P}\left(\mathrm{H}_{2} \mathrm{O}\right)=10^{-2}$ bar and $\mathrm{P}\left(\mathrm{NH}_{3}\right)=$ $10^{-3}$ bar (co-adsorption of ammonia and water). $2.3 \AA$ is the threshold copper-ligand distance value.

We are aware that the approximations made in the present work for the evaluation of the adsorption free energy (in particular, the entropic contributions) lead to uncertainties in the positions of the frontiers in the stability diagrams. As suggested previously, ${ }^{34,43,75}$ the 
increased mobility of copper with increasing adsorbate loading may lead to an increase of the residual rotational and translational entropy in the adsorbed state. The entropy in the adsorbed state may not be accurately rendered by the sole estimation of the vibrational degrees of freedom. The residual rotational and translational entropy in the adsorbed state however depends on the adsorption site and of the presence of co-adsorbates, ${ }^{75}$ making the full resolution of this question very challenging. Some improvements of these aspects should be achieved in future, e.g. by systematic molecular dynamics investigations, in the spirit of investigations performed for simpler cases in refs. ${ }^{75-76}$.

\subsection{Water and ammonia co-adsorption considered by DFT calculations}

The same approach was chosen to model the co-adsorption of water (n molecules) and ammonia ( $m$ molecules), resulting in systems denoted $(n, m)$, for $n+m \leq 6$, for copper at both $6 \mathrm{MR}$ and $8 \mathrm{MR}$. To the best of our knowledge, such a systematic study is not reported in the literature yet. The $(1,1)$ systems (co-adsorption of one water molecule plus one ammonia molecule) are represented in Figure 6 (all most stable structures found for each (n, m) values are reported in the Supporting Information S3). Basically, the same trends are observed as for the adsorption of water or ammonia alone, in terms of gradual loss of coordination between copper and the zeolite framework, which generally takes place for $n+m \geq 4$ (with a few exceptions). 

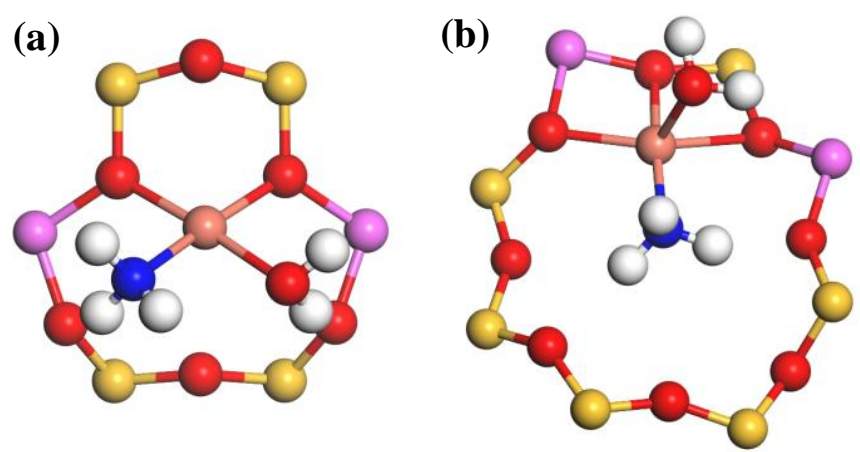

$\odot \mathrm{Si} \odot \mathrm{O} \odot \mathrm{Cu} \odot \mathrm{Al} \bullet \mathrm{N} \bigcirc \mathrm{H}$

Figure 6. Structures of the $(1,1)$ configurations (one water molecule, one ammonia molecule) at $\mathrm{Cu}^{\mathrm{II}}$ in $6 \mathrm{MR}$ (a) and $8 \mathrm{MR}(\mathrm{b})$.

The cumulated adsorption energy for each $(n, m)$ value are plotted in Figure S4. Trends are rather constant upon increase of the number of coordinated molecules, with a systematically higher adsorption energy (in absolute value) for $8 \mathrm{MR}$. This shift with respect to 6MR is due to the lower initial coordination number inducing higher adsorption energies for the first molecule (water or ammonia). 2D phase diagrams are represented in Figure 7 with the temperature and either $\mathrm{P}\left(\mathrm{H}_{2} \mathrm{O}\right)$ (at constant $\mathrm{P}\left(\mathrm{NH}_{3}\right)=10^{-3}$ bar) or $\mathrm{P}\left(\mathrm{NH}_{3}\right)$ (at constant $\mathrm{P}\left(\mathrm{H}_{2} \mathrm{O}\right)=$ $10^{-2}$ bar). Complementary diagrams were drawn for other pressure conditions in Supporting Information S7. 
(a)

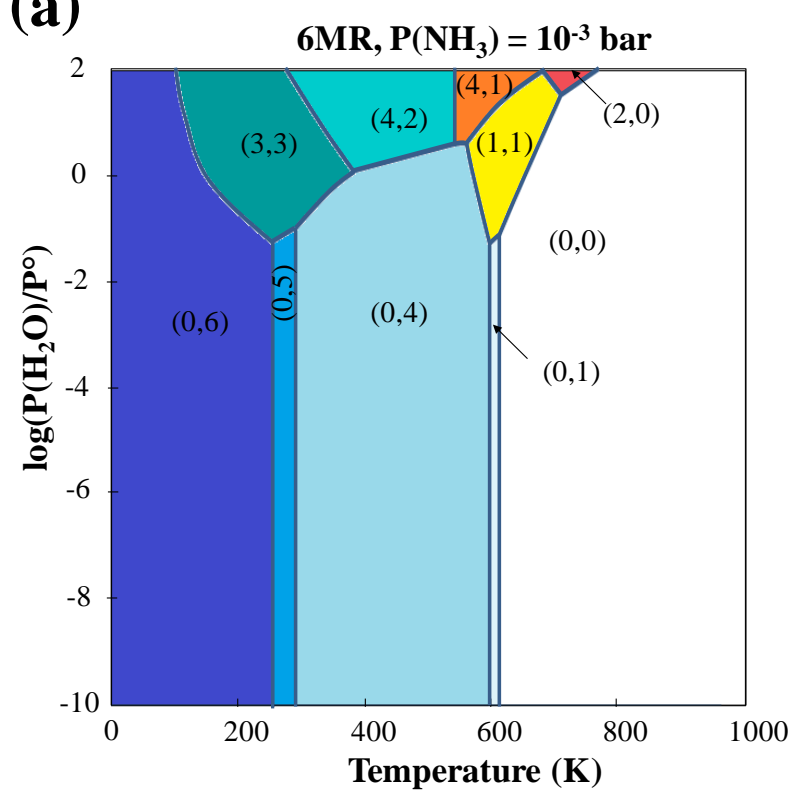

(c)

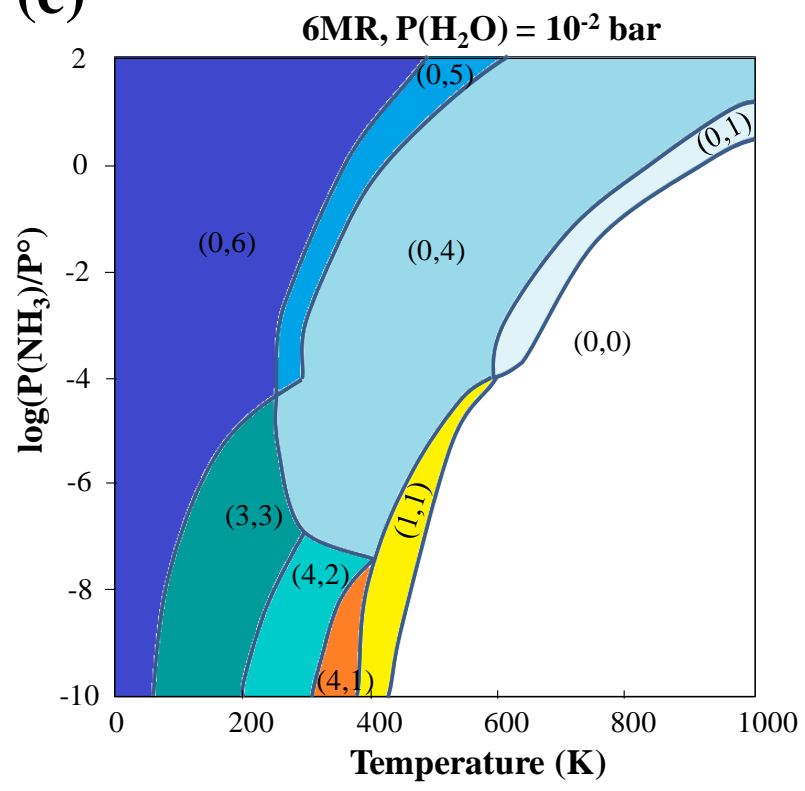

(b)

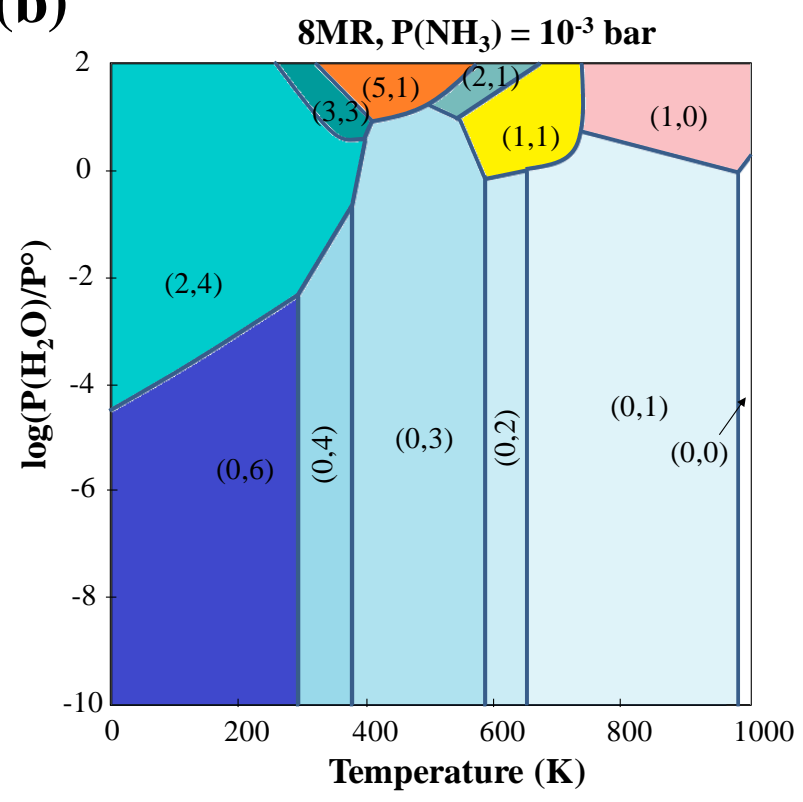

(d)

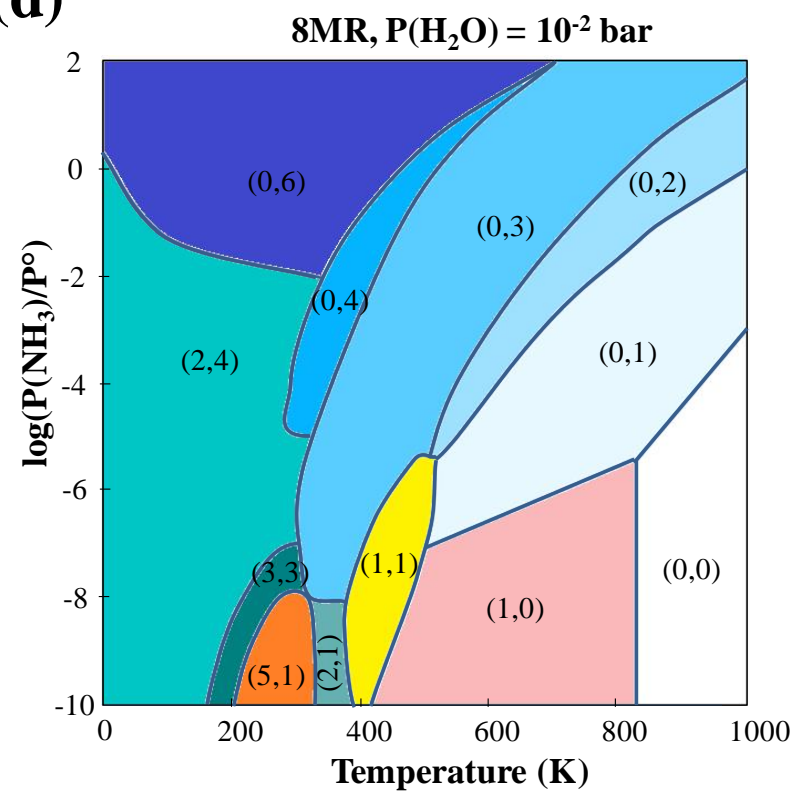

Figure 7. Phase diagrams obtained from DFT calculations for $\mathrm{H}_{2} \mathrm{O}$ and $\mathrm{NH}_{3}$ co-adsorption at $6 \mathrm{MR}$ (a) and (c), and 8MR (b) and (d). Diagrams are drawn as a function of (a) and (b) $\mathrm{P}\left(\mathrm{H}_{2} \mathrm{O}\right)$ (at constant $\mathrm{P}\left(\mathrm{NH}_{3}\right)=10^{-3}$ bar) or (c) and (d) $\mathrm{P}\left(\mathrm{NH}_{3}\right)$ (at constant $\mathrm{P}\left(\mathrm{H}_{2} \mathrm{O}\right)=10^{-2}$ bar). The most stable systems in the given conditions are called $(\mathrm{n}, \mathrm{m}), \mathrm{n}$ being the number of water molecules, $\mathrm{m}$ the number of ammonia molecule per $\mathrm{Cu}^{\mathrm{II}}$.

The interaction with ammonia dominates under most of the conditions, which can be clearly seen by the vertical domains occupying the largest part of the diagrams drawn at 
constant $\mathrm{P}\left(\mathrm{NH}_{3}\right)$. These domains correspond to systems where no water molecules are present in the coordination sphere of copper. Mixed systems are also encountered, such as the $(1,1)$ systems, both on $6 \mathrm{MR}$ and $8 \mathrm{MR}$, typically for temperatures around $400-600 \mathrm{~K}, \mathrm{P}\left(\mathrm{NH}_{3}\right)<10^{-4}$ bar for $\mathrm{P}\left(\mathrm{H}_{2} \mathrm{O}\right)=10^{-2}$ bar (Figure 7-(c) and $\left.-(\mathrm{d})\right)$. If we come back to $\mathrm{P}\left(\mathrm{H}_{2} \mathrm{O}\right)=10^{-2}$ bar and $\mathrm{P}\left(\mathrm{NH}_{3}\right)=10^{-3}$ bar (the conditions selected for the sake of comparison with experimental results) it appears that the most stable systems under these conditions are almost the same as the one in pure ammonia at $\mathrm{P}\left(\mathrm{NH}_{3}\right)=10^{-3}$ bar. Hence, the diagram of Figure 4-(b), representing the most stable structure if $\mathrm{NH}_{3}$ only is present, is still valid in this case.

\subsection{Adsorption of water and ammonia identified by XANES}

In situ X-ray absorption spectroscopy in terms of XANES and EXAFS was used to probe the interaction of $\mathrm{Cu}$ species with ammonia and water under relevant operating conditions of $\mathrm{Cu}-\mathrm{SSZ}-13 \mathrm{SCR}$ catalysts, in order to estimate the validity of the theoretical calculations. We exploited that XANES at the $\mathrm{Cu} \mathrm{K}$ edge is very sensitive to the oxidation state and geometry of $\mathrm{Cu}$ complexes, especially if HERFD-XANES is regarded. ${ }^{71,77}$ This allows distinguishing between $\mathrm{Cu}^{\mathrm{II}}$ species with different coordination numbers, $\mathrm{Cu}^{\mathrm{I}} \cdot \mathrm{xNH}_{3}$ (species coordinated with ammonia), and $\mathrm{Cu}^{\mathrm{I}}$ species not coordinated with ammonia. The corresponding spectral features have been assigned in detail in the previous studies ${ }^{35-36}$ using HERFD-XANES and X-ray emission spectroscopy. The HERFD-XANES spectra reported earlier ${ }^{35}$ together with the corresponding conventional XANES spectra used for data analysis in this work can be found in the Supporting Information S1. 

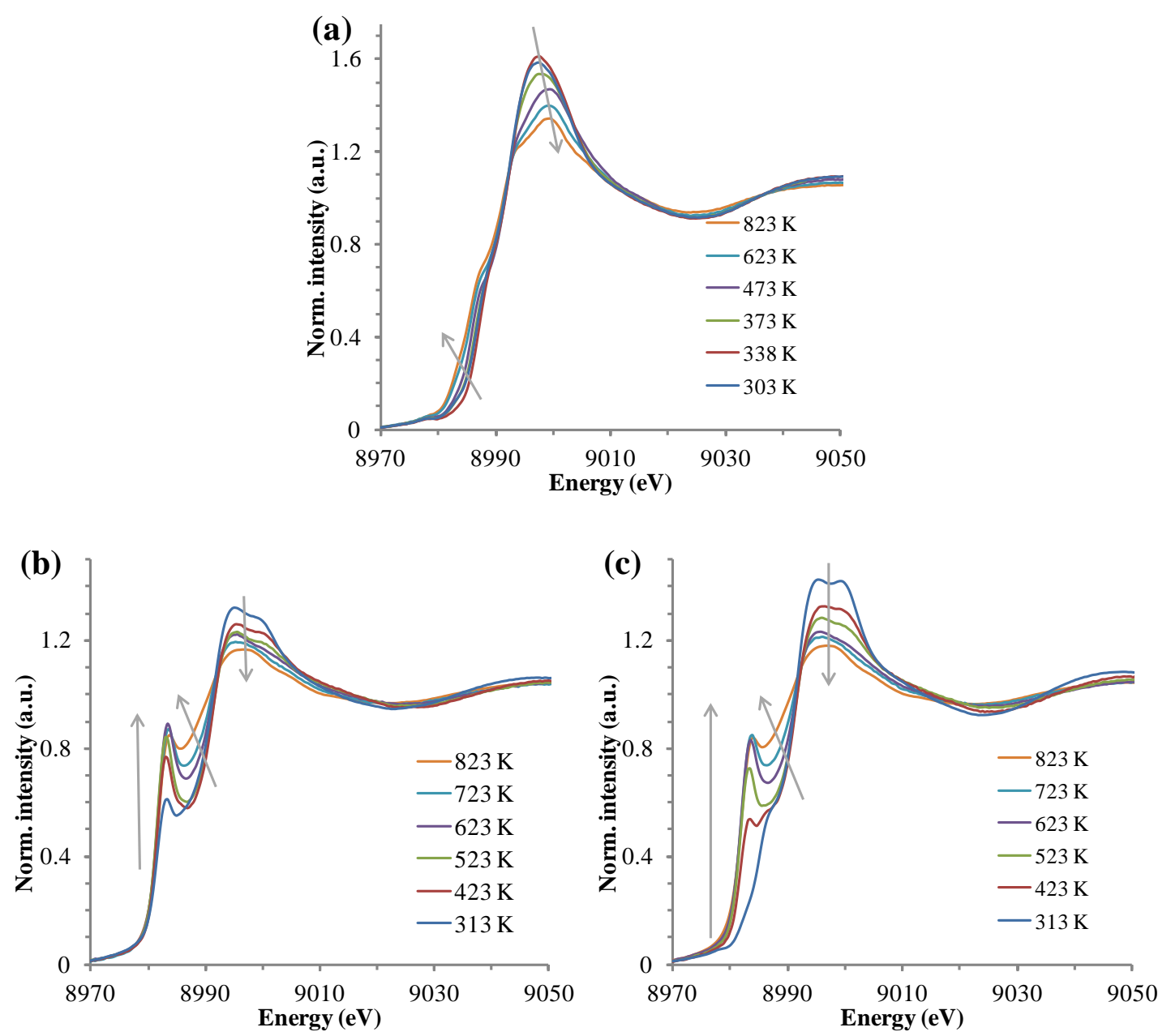

Figure 8. Selected XANES spectra at $\mathrm{Cu} \mathrm{K}$ edge obtained during heating Cu-SSZ-13 zeolite in a flow of (a) He with $\mathrm{P}\left(\mathrm{O}_{2}\right)=10^{-2}$ bar and $\mathrm{P}\left(\mathrm{H}_{2} \mathrm{O}\right)=10^{-5}$ bar, (b) He with $\mathrm{P}\left(\mathrm{NH}_{3}\right)=10^{-3}$ bar, and (c) He with $\mathrm{P}\left(\mathrm{NH}_{3}\right)=10^{-3}$ bar and $\mathrm{P}\left(\mathrm{H}_{2} \mathrm{O}\right)=10^{-2}$ bar. Temperature ramp rate $10 \mathrm{~K} / \mathrm{min}$.

Prior to the in situ X-ray absorption measurements involving $\mathrm{NH}_{3}$, the as-received hydrated Cu-SSZ-13 catalyst was dehydrated in oxidizing atmosphere $\left(10 \% \mathrm{O}_{2}\right.$ in $\left.\mathrm{He}\right)$ during heating to $823 \mathrm{~K}$, similar to the procedure reported by Borfecchia et al. ${ }^{16}$ The gas mixture was not additionally dried and contained approx. $10 \mathrm{ppm}\left(10^{-5}\right.$ bar $) \mathrm{H}_{2} \mathrm{O}$. As reported in the section 3.3, under typical catalyst operating conditions $\left(\mathrm{T}>300 \mathrm{~K}, \mathrm{P}\left(\mathrm{H}_{2} \mathrm{O}\right) \leq 10^{-1}\right.$ bar, $\mathrm{P}\left(\mathrm{NH}_{3}\right)>10^{-4}$ bar) adsorbed ammonia dominates on $\mathrm{Cu}$ sites. Hence, observing the stability of $\mathrm{H}_{2} \mathrm{O}$ complexes in $\mathrm{NH}_{3}$-containing gas feeds or reaching $\mathrm{NH}_{3}-\mathrm{H}_{2} \mathrm{O}$ transition regions in experiments designed to study exhaust gas catalysis is often not possible, as shown by 
theoretical calculations. Hence, the stability of aqueous $\mathrm{Cu}^{\mathrm{II}}$ complexes in the zeolite matrix was evaluated in the dehydration gas mixture (without $\mathrm{NH}_{3}$ ). Figure 8-(a) reports XANES spectra of $\mathrm{Cu}^{\mathrm{II}}$ sites recorded during the dehydration experiment. The spectra can be attributed to $\mathrm{Cu}^{\text {II }}$ sites with different geometries ${ }^{16,35-36}$ but linear combination analysis in this case was not successful, possibly due to need to account for a mixture of co-existing species $\left(\mathrm{Cu}^{\mathrm{II}}\right.$ in $6 \mathrm{MR}$ and $8 \mathrm{MR})^{16}$ each changing geometry at different temperatures. Hence, transformations of $\mathrm{Cu}$ species were followed qualitatively by following the energy shift of the rising edge at a normalized absorbance 0.2 (Figure 9-(a)) and a maximum of the white line (peak at approx. $9000 \mathrm{eV}$, Figure S6). $\mathrm{Cu}^{\mathrm{II}}$ site restructuring occurring at approx. $340 \mathrm{~K}$ and $673 \mathrm{~K}$ can be seen which can be attributed to water desorption from $\mathrm{Cu}^{\mathrm{II}}$ in $6 \mathrm{MR}$ and $8 \mathrm{MR}$, respectively (Figure 4-(a)). The outlier datapoint at $338 \mathrm{~K}$ is not an artifact but indeed lies on top of a volcano as confirmed by evaluation of spectra recorded at $313 \mathrm{~K}$ and $343 \mathrm{~K}$ (not shown).

After the dehydration experiment and the subsequent cooling down the gas feed was switched to He with only $\mathrm{NH}_{3}$ or $\mathrm{NH}_{3}$ and $\mathrm{H}_{2} \mathrm{O}$. The gas feed contained no oxygen to prevent $\mathrm{NH}_{3}$ oxidation reaction. The catalyst was kept for 10 min at $313 \mathrm{~K}$ after which continuous heating to $823 \mathrm{~K}$ started. Already at $313 \mathrm{~K}$ interaction with ammonia in the dry feed led to appearance of a prominent peak at the rising edge $(8983 \mathrm{eV})$ in the XANES spectra (Figure 8(b)). This edge feature has been previously assigned to $1 \mathrm{~s} \rightarrow 4 \mathrm{p}$ transition in two-coordinated $\mathrm{Cu}^{\mathrm{I}}$ complexes $^{34}$ and suggests partial reduction of $\mathrm{Cu}^{\mathrm{II}}$ sites due to interaction with ammonia already at ambient conditions. During further heating the $\mathrm{Cu}^{\mathrm{I}}$ fingerprint becomes more intense and above $523 \mathrm{~K}$ the shape of the rising edge changes. This indicates a change in the structure of the $\mathrm{Cu}^{\mathrm{I}}$ complexes. If the same experiment is repeated in the presence of water vapor $\left(\mathrm{P}\left(\mathrm{H}_{2} \mathrm{O}\right)=10^{-2}\right.$ bar, Figure $\left.8-(\mathrm{c})\right)$, different spectra are obtained below $423 \mathrm{~K}$. The spectrum recorded at $313 \mathrm{~K}$ reveals a shoulder at $8988 \mathrm{eV}$ ascribed to $1 \mathrm{~s} \rightarrow 4 \mathrm{p}$ transition with ligand to metal charge transfer in $\mathrm{Cu}^{\mathrm{II}}$ complexes ${ }^{36,78}$ and no $\mathrm{Cu}^{\mathrm{I}}$ fingerprint. The spectrum 
measured at $423 \mathrm{~K}$ shows a mixture of $\mathrm{Cu}^{\mathrm{I}}$ and $\mathrm{Cu}^{\mathrm{II}}$ features whereas spectra measured at higher temperatures correspond to the ones recorded in the dry feed. Hence, interaction of $\mathrm{Cu}$ sites with water vapor is probably limited to low temperatures $(<423 \mathrm{~K})$, where water inhibits $\mathrm{Cu}^{\mathrm{II}}$ reduction by ammonia.

(a)

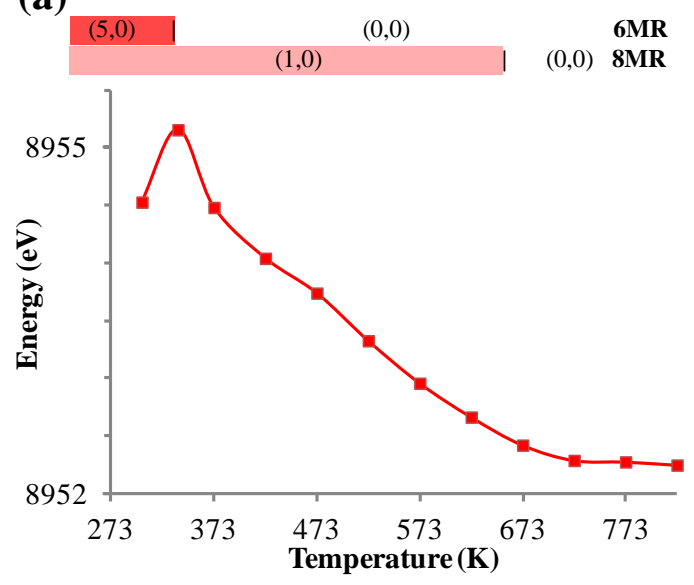

(b)

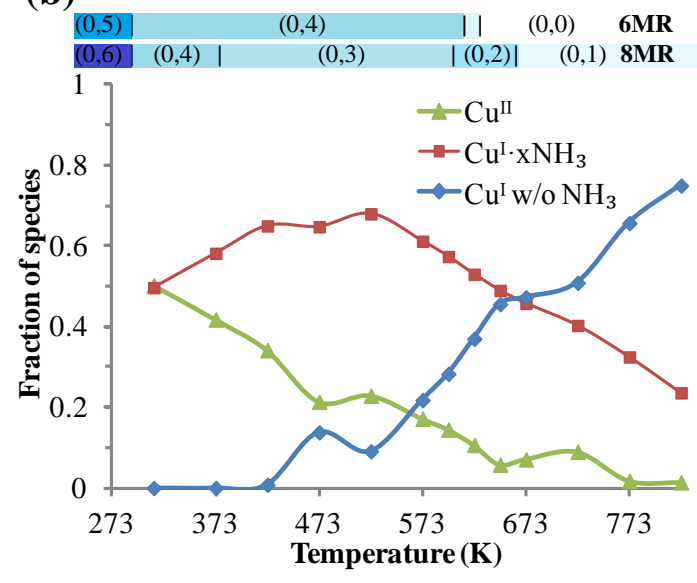

(c)

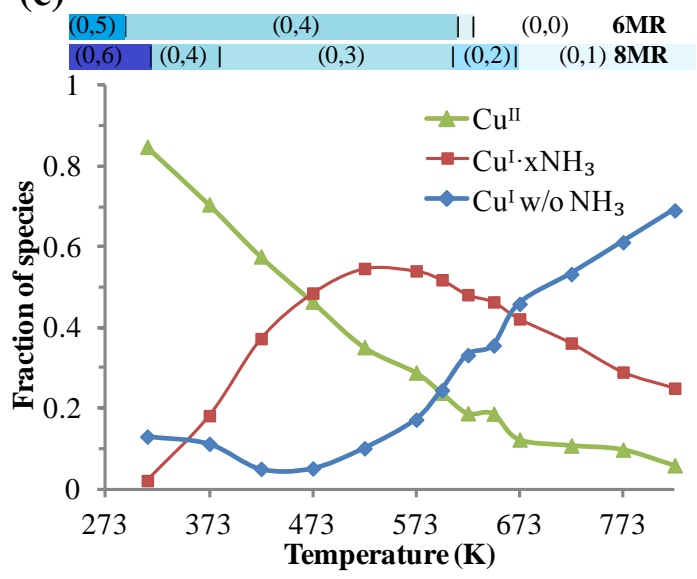

Figure 9. Results of LCA of XANES spectra at $\mathrm{Cu}$ K edge obtained during heating Cu-SSZ-13 zeolite in a flow of (a) He with $\mathrm{P}\left(\mathrm{O}_{2}\right)=10^{-2}$ bar and $\mathrm{P}\left(\mathrm{H}_{2} \mathrm{O}\right)=10^{-5}$ bar, (b) He with $\mathrm{P}\left(\mathrm{NH}_{3}\right)=10^{-3}$ bar, and (c) He with $\mathrm{P}\left(\mathrm{NH}_{3}\right)=10^{-}$ ${ }^{3}$ bar and $\mathrm{P}\left(\mathrm{H}_{2} \mathrm{O}\right)=10^{-2}$ bar. Temperature ramp rate $10 \mathrm{~K} / \mathrm{min}$. Text lines on top of the graphs depict theoretical stability regions for $\mathrm{Cu}$ sites with $\mathrm{H}_{2} \mathrm{O}$ and $\mathrm{NH}_{3}$ ligands at $6 \mathrm{MR}$ and 8MR (derived from Figures 3, 4 and 7).

In order to quantify the states of $\mathrm{Cu}$ from the XANES spectra with $\mathrm{NH}_{3}$ in the system linear combination analysis (LCA) using a priori known reference spectra was performed 
(Figure 9). We could distinguish $\mathrm{Cu}^{\mathrm{II}}$ species (which may or may not have $\mathrm{NH}_{3}$ in the coordination sphere) and two types of $\mathrm{Cu}^{\mathrm{I}}$ complexes: containing $\mathrm{NH}_{3}$ ligands $\left(\mathrm{Cu}^{\mathrm{I}} \cdot \mathrm{xNH}_{3}\right)$ and $\mathrm{Cu}^{\mathrm{I}}$ without $\mathrm{NH}_{3}$ in the coordination sphere. When gas feed without water was used, about $50 \%$ reduction of $\mathrm{Cu}^{\mathrm{II}}$ sites was observed already at $313 \mathrm{~K}$, and all $\mathrm{Cu}^{\mathrm{I}}$ species were coordinated with $\mathrm{NH}_{3}$ (Figure 9-(b)). At elevated temperatures the fraction of $\mathrm{Cu}^{\mathrm{I}} \cdot \mathrm{xNH}_{3}$ sites constantly increased reaching a maximum at $523 \mathrm{~K}$, above which desorption of $\mathrm{NH}_{3}$ started to occur. The fraction of $\mathrm{Cu}^{\mathrm{I}}$ species without $\mathrm{NH}_{3}$ in the coordination sphere started to grow and became the most abundant one above $623 \mathrm{~K}$. This is in agreement with the DFT calculations which predict under these conditions complete desorption of $\mathrm{NH}_{3}$ from $\mathrm{Cu}$ sites at $6 \mathrm{MR}$ and partial desorption from $\mathrm{Cu}$ sites located at 8MR (Figure 7-(c) and -(d)). If water vapor was present together with $\mathrm{NH}_{3}$, the $\mathrm{Cu}^{\mathrm{II}}$ reduction was inhibited in the low temperature region (Figure 9-(c)). However, with temperature increase above $473 \mathrm{~K}, \mathrm{Cu}^{\mathrm{I}} \cdot \mathrm{xNH}_{3}$ species became dominating species. Above $523 \mathrm{~K}$ the influence of $\mathrm{H}_{2} \mathrm{O}$ could not be observed: the spectra measured at $\mathrm{P}\left(\mathrm{NH}_{3}\right)=10^{-3}$ bar were similar to the ones measured at $\mathrm{P}\left(\mathrm{NH}_{3}\right)=10^{-3}$ bar and $\mathrm{P}\left(\mathrm{H}_{2} \mathrm{O}\right)=10^{-2}$ bar. Note that the thermodynamic stability of $\mathrm{NH}_{3}$ adsorbed on $\mathrm{Cu}^{\mathrm{I}}$ and $\mathrm{Cu}^{\mathrm{II}}$ species located in 6MR was previously modeled by Paolucci et al. ${ }^{43}$ and was shown to hardly depend on the oxidation state of $\mathrm{Cu}$ sites. Hence, the predicted temperature of complete $\mathrm{NH}_{3}$ desorption does not strongly depend on the choice of $\mathrm{Cu}^{\mathrm{I}}$ or $\mathrm{Cu}^{\mathrm{II}}$ as a model site for the DFT calculations, and both models agree with the experimental observations.

\subsection{Coordination numbers in the first coordination sphere of $C u$ sites identified by EXAFS}

Fourier transformed (FT) EXAFS spectra obtained during heating the Cu-SSZ-13 in the different gas feeds are reported in Figure 10-(a),(c),(e). Analysis of the EXAFS data allows obtaining average coordination numbers and bond distances (detailed structural information is 
reported in Supporting Information S9). As reported earlier for Fe- and Cu-zeolite SCR catalysts, the first shell consisting of $\mathrm{O}$ or $\mathrm{N}$ atoms can be clearly observed. ${ }^{5}$ Heating the $\mathrm{Cu}$ SSZ-13 in all cases led to the decrease of the backscattering intensity due to decreasing coordination numbers. Results of EXAFS analysis are summarized in Tables S6-S8 and dynamics of the total coordination number $(\mathrm{CN})$ in the first shell is shown in Figure 10(b),(d),(f). During the dehydration experiment, first shell CNs changed in three steps caused by desorption of water ligands and rearrangement of $\mathrm{Cu}^{\mathrm{II}}$ sites in the zeolite framework. The existence of two steps and the transition temperatures qualitatively agree with results of XANES analysis and theoretical predictions. At first, $\mathrm{H}_{2} \mathrm{O}$ is desorbed from $\mathrm{Cu}^{\mathrm{II}}$ sites in $6 \mathrm{MR}$ (average $\mathrm{CN}$ changes from 4.3 to 3.7 , corresponding to a change of $30 \% \mathrm{Cu}^{\mathrm{II}}$ sites from 5 to 3 nearest neighbors). Then, at temperatures above $670 \mathrm{~K}$, a further stepwise change of the average $\mathrm{CN}$ from 3.7 to 3.0 occurs, which can be explained by $70 \%$ of $\mathrm{Cu}$ sites (8MR sites) losing one water ligand. The co-existence of $6 \mathrm{MR}$ and $8 \mathrm{MR}$ sites as well as their relative fractions agree well with HERFD-XANES modeling performed by Borfecchia et al. ${ }^{16}$

Introduction of $\mathrm{NH}_{3}$ in the system significantly changed the corresponding EXAFS spectra. The backscattering intensity from the first coordination shell dropped down in the spectra measured in the presence of both $\mathrm{NH}_{3}$ and $\mathrm{H}_{2} \mathrm{O}$ (Figure 10-(e)), and even more significantly in the spectra measured in dry $\mathrm{NH}_{3}$ below $523 \mathrm{~K}$ (Figure 10-(c)). Above this temperature, as in the case of XANES spectra, no effect of water was observed. 

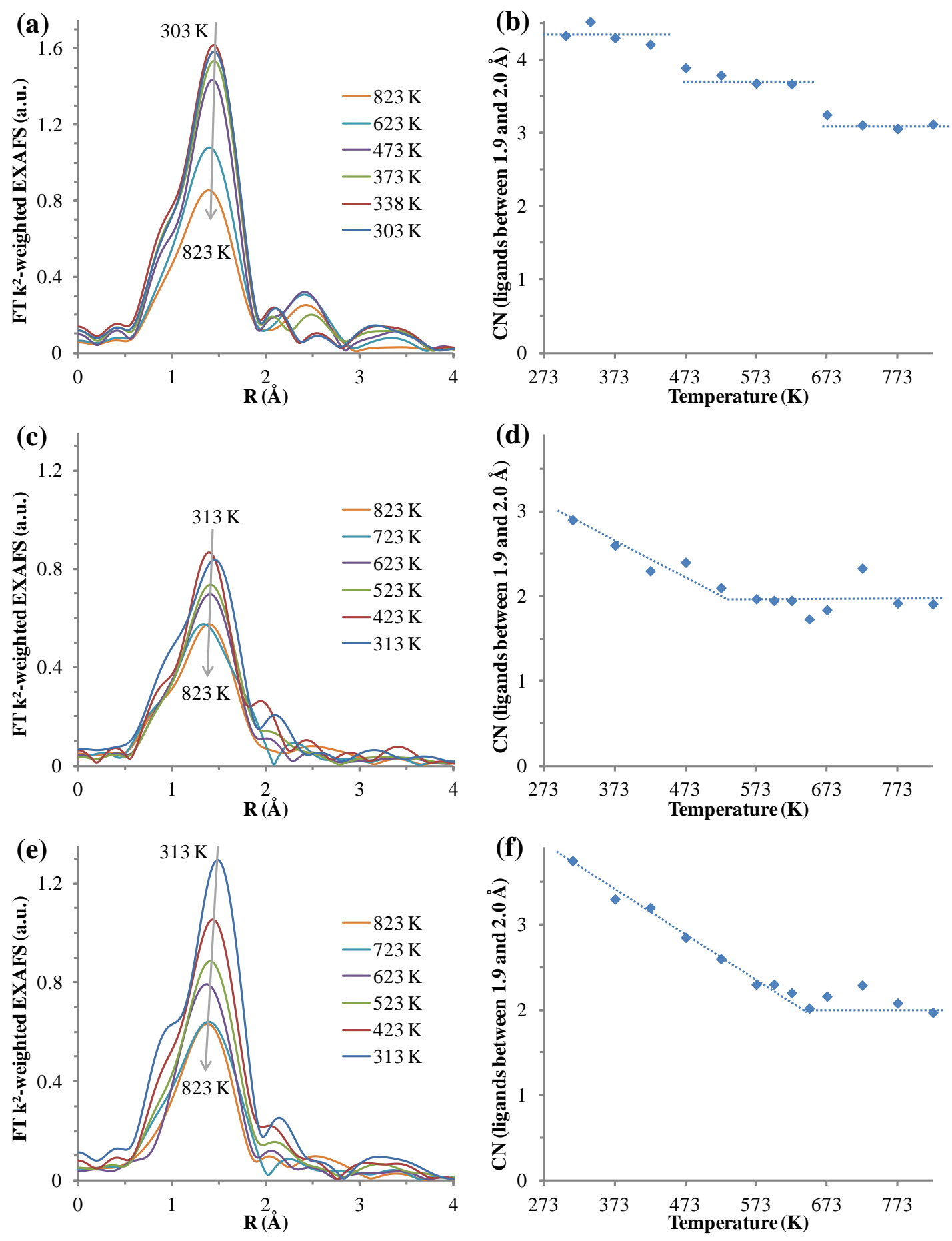

Figure 10. Fourier transformed $\mathrm{k}^{2}$-weighted EXAFS spectra (not corrected for the phase shift) at $\mathrm{Cu} \mathrm{K}$ edge (a), (c), (e) and coordination numbers in the first shell $(\mathrm{R}=1.9-2 \AA)$ derived from the analysis of the EXAFS spectra (b), (d), (f) obtained during heating Cu-SSZ-13 zeolite in a flow of He containing (a) anb (b) $\mathrm{P}\left(\mathrm{O}_{2}\right)=10^{-2}$ bar (with rest $\mathrm{P}\left(\mathrm{H}_{2} \mathrm{O}\right)=10^{-5}$ bar, i.e. dehydration experiment); (c) and (d) $\mathrm{P}\left(\mathrm{NH}_{3}\right)=10^{-3}$ bar; (e) and (f) $\mathrm{P}\left(\mathrm{NH}_{3}\right)=$ $10^{-3}$ bar and $\mathrm{P}\left(\mathrm{H}_{2} \mathrm{O}\right)=10^{-2}$ bar. Temperature ramp rate $10 \mathrm{~K} / \mathrm{min}$. 
Without water in the feed the average $\mathrm{CN}$ was 3 already at the start of heating and it decreased to 2 at $523 \mathrm{~K}$, after which it was stable (Figure 10-(d)). The initial CN of 3 agrees well with coexistence of $50 \% \mathrm{Cu}^{\mathrm{II}}(\mathrm{CN}=4$, in accordance with DFT analysis performed in this study (Figure 5) and earlier analyses ${ }^{43,73}$ ) and $50 \% \mathrm{Cu}^{\mathrm{I}}$ (for which $\mathrm{CN}=2$ is the most preferable coordination number from $\mathrm{DFT}^{73}$ and has been identified previously by XANES). ${ }^{77}$ Even though $\mathrm{NH}_{3}$ desorbs from $\mathrm{Cu}$ sites at $\mathrm{T}>523 \mathrm{~K}$, its place in the coordination sphere of $\mathrm{Cu}^{\mathrm{I}}$ is occupied by $\mathrm{O}$ atoms from the zeolite framework, and the resulting $\mathrm{CN}$ stays unchanged upon further heating. In the case of $\mathrm{Cu}-\mathrm{SSZ}-13$ heating at $\mathrm{P}\left(\mathrm{NH}_{3}\right)=10^{-3}$ bar and $\mathrm{P}\left(\mathrm{H}_{2} \mathrm{O}\right)=10^{-2}$ bar, the original coordination is close to 4 in agreement with dominating $\mathrm{Cu}^{\mathrm{II}}$ species, but it decreases to 2 as $\mathrm{Cu}^{\mathrm{II}}$ species are reduced to $\mathrm{Cu}^{\mathrm{I}}$ upon heating. This variation suggests that water desorbs from $\mathrm{Cu}^{\mathrm{II}}$ sites at $\mathrm{T}>300 \mathrm{~K}$ under experimental conditions (Figure 7-(c),(d)) and is completely desorbed at $523 \mathrm{~K}$ even if higher local concentration of water vapor is present (Figure 3-(a),(b)). Therefore, at low temperatures water acts as a stabilizer of $\mathrm{Cu}^{\mathrm{II}}$ species. As soon as water molecules desorb (approx. $300-$ $500 \mathrm{~K}$, according to the calculations), $\mathrm{Cu}^{\mathrm{II}}$ sites undergo reduction to $\mathrm{Cu}^{\mathrm{I}}$, resulting in the experimentally observed change of the coordination numbers from 4 to 2 (Figure 10-(d)-(f)). Hence, the coordination numbers retrieved from EXAFS during $\mathrm{H}_{2} \mathrm{O} / \mathrm{NH}_{3}$ desorption indicate an overall decrease of the number of $\mathrm{NH}_{3}$ ligands, which is supported by the reported analysis of the XANES region (Figure 9). However, the EXAFS region is also strongly sensitive to the oxidation state of $\mathrm{Cu}$, and points at the redox behavior simultaneously with the adsorptiondesorption behavior of $\mathrm{NH}_{3}$ and $\mathrm{H}_{2} \mathrm{O}$, as observed also by Paolucci et al. ${ }^{43}$

\section{CONCLUSIONS}

A theoretical mapping of the coordination sphere of $\mathrm{Cu}^{\mathrm{II}}$ in SSZ-13 in the presence of $\mathrm{H}_{2} \mathrm{O}$ and/or $\mathrm{NH}_{3}$ was reached from DFT calculations for copper located at the $6 \mathrm{MR}$ or at the $8 \mathrm{MR}$ 
site. The $8 \mathrm{MR}$ site appears to significantly stabilize adsorbates in the coordination sphere of copper. The interaction of ammonia with $\mathrm{Cu}^{\mathrm{II}}$ ions is stronger than the one with water, which makes ammonia to dominate the phase diagrams even for higher water pressures. Oxygen atoms from the zeolitic framework are involved in the coordination sphere of $\mathrm{Cu}^{\mathrm{II}}$ for low $\mathrm{P}\left(\mathrm{NH}_{3}\right)$ or $\mathrm{P}\left(\mathrm{H}_{2} \mathrm{O}\right)$ values and high desorption temperatures, leading to almost constant coordination numbers (4 neighbors) over a wide range of conditions. For high ammonia concentrations and low temperatures $\mathrm{Cu}^{\mathrm{II}}$ disconnects from the framework and becomes mobile in the zeolite cavity.

The theoretical predictions were validated by in situ XAS. Desorption of water ligands from $\mathrm{Cu}^{\mathrm{II}}$, reduction of $\mathrm{Cu}^{\mathrm{II}}$ to $\mathrm{Cu}^{\mathrm{I}}$ in the $\mathrm{NH}_{3}$-containing atmosphere and high stability of $\mathrm{NH}_{3}$-containing complexes were observed by in situ X-ray absorption spectroscopy. The effect of water presence in the $\mathrm{NH}_{3}$-containing gas feed was visible below $423 \mathrm{~K}$ in form of inhibition of $\mathrm{Cu}^{\mathrm{II}}$ to $\mathrm{Cu}^{\mathrm{I}}$ reduction. Trends in terms of water and ammonia desorption temperatures were well reproduced by the analysis of the XANES region, with significant desorption of $\mathrm{NH}_{3}$ from $\mathrm{Cu}$ sites at about $673 \mathrm{~K}$ at $\mathrm{P}\left(\mathrm{NH}_{3}\right)=10^{-3}$ bar in the presence or absence of $\mathrm{H}_{2} \mathrm{O}$. The variation of the coordination numbers obtained from EXAFS analysis confirms stepwise $\mathrm{H}_{2} \mathrm{O}$ desorption from $6 \mathrm{MR}$ and $8 \mathrm{MR} \mathrm{Cu}^{\text {II }}$ sites near the predicted temperatures and supports $\mathrm{NH}_{3}$ desorption tendency at higher temperatures. Coordination numbers obtained from EXAFS analysis also follow the reduction of $\mathrm{Cu}^{\mathrm{II}}$ to $\mathrm{Cu}^{\mathrm{I}}$ in the $\mathrm{NH}_{3^{-}}$ containing atmosphere. Hence, the convoluted behaviors of $\mathrm{Cu}^{\mathrm{I}}$ and $\mathrm{Cu}^{\mathrm{II}}$ open new perspectives for the computational investigation of the systematic behavior of $\mathrm{Cu}^{\mathrm{I}}$ in $\mathrm{H}_{2} \mathrm{O} / \mathrm{NH}_{3}$ atmosphere, and of the mechanism of $\mathrm{Cu}^{\mathrm{II}}$ to $\mathrm{Cu}^{\mathrm{I}}$ reduction in the presence of $\mathrm{NH}_{3}$.

\section{ASSOCIATED CONTENT}


Supporting Information contains: reference spectra used to evaluate XANES data; computational sampling of respective locations for aluminum and copper in $\mathrm{Cu}$-SSZ-13; most stable structures found by DFT calculations; adsorption energies of water or ammonia; structural analysis for the species expected at $\mathrm{P}\left(\mathrm{NH}_{3}\right)=10^{-3}$ bar (adsorption of ammonia alone), or for $\mathrm{P}\left(\mathrm{H}_{2} \mathrm{O}\right)=10^{-2}$ bar and $\mathrm{P}\left(\mathrm{NH}_{3}\right)=10^{-3}$ bar (co-adsorption of ammonia and water); adsorption energies of water plus ammonia; thermodynamic diagrams for ammonia and water co-adsorption for $\mathrm{P}\left(\mathrm{H}_{2} \mathrm{O}\right)=10^{-1}$ bar; evolution of the white line (peaks around $9000 \mathrm{eV}$ ) intensity in the XANES spectra recorded during dehydration of $\mathrm{Cu}^{\mathrm{II}}$ sites; structural analysis of the first coordination shell of $\mathrm{Cu}$ species during heating $\mathrm{Cu}-\mathrm{SSZ}-13$ zeolite in a dehydration experiment and a gas mixture containing $\mathrm{P}\left(\mathrm{NH}_{3}\right)=10^{-3}$ bar (ammonia alone), or at $\mathrm{P}\left(\mathrm{H}_{2} \mathrm{O}\right)=$ $10^{-2}$ bar and $\mathrm{P}\left(\mathrm{NH}_{3}\right)=10^{-3}$ bar (co-feeding of ammonia and water); coordinates of all simulated systems.

\section{Acknowledgment}

The research leading to the DFT results has received funding (project PRESTIGE-2015-30024) from the People Program (Marie Curie Actions) of the European Union's Seventh Framework Program (FP7) under REA grant agreement PCOFUND-GA-2013-609102, through the PRESTIGE program coordinated by Campus France. BK acknowledges IFP Energies nouvelles for a visiting professorship. The calculations have been performed on the French national centers of high performance IDRIS under project 100551 as well as the ENER110 supercomputer at IFP Energies nouvelles. JDG and MC acknowledge the support by a DFG-grant (GR 3987/5-1) and Deniz Zengel (KIT). We acknowledge the Paul Scherrer Institut, Villigen, Switzerland for provision of synchrotron radiation beamtime at beamline X10DA (Super-XAS) of the SLS and would like to thank Dr. Maarten Nachtegaal for 
assistance in using the beamline as well as Dr. Oliver Müller (BU Wuppertal) and Dr. Amir Reza Fahami (PoliMi and KIT) for help during the measurements. Dr. Tobias Günter (KIT) is acknowledged for sample preparation and support during the measurements.

\section{Notes}

The authors declare no competing financial interest. 


\section{REFERENCES}

(1) von Schneidemesser, E.; Monks, P. S.; Allan, J. D.; Bruhwiler, L.; Forster, P.; Fowler, D.; Lauer, A.; Morgan, W. T.; Paasonen, P.; Righi, M.et al, Chemistry and the Linkages between Air Quality and Climate Change, Chem. Rev. 2015, 115, 3856-3897.

(2) Brandenberger, S.; Kröcher, O.; Tissler, A.; Althoff, R., The State of the Art in Selective Catalytic Reduction of NOx by Ammonia Using Metal-Exchanged Zeolite Catalysts, Catal. Rev. 2008, 50, 492-531.

(3) Deka, U.; Lezcano-Gonzalez, I.; Weckhuysen, B. M.; Beale, A. M., Local Environment and Nature of $\mathrm{Cu}$ Active Sites in Zeolite-Based Catalysts for the Selective Catalytic Reduction of NOx, ACS Catalysis 2013, 3, 413-427.

(4) Beale, A. M.; Gao, F.; Lezcano-Gonzalez, I.; Peden, C. H. F.; Szanyi, J., Recent Advances in Automotive Catalysis for NOx Emission Control by Small-Pore Microporous Materials, Chem. Soc. Rev. 2015, 44, 7371-7405.

(5) Doronkin, D. E.; Casapu, M.; Guenter, T.; Mueller, O.; Frahm, R.; Grunwaldt, J.-D., Operando Spatially- and Time-Resolved XAS Study on Zeolite Catalysts for Selective Catalytic Reduction of NOx by $\mathrm{NH}_{3}, J$. Phys. Chem. C 2014, 118, 10204-10212.

(6) Ganemi, B.; Bjornbom, E.; Paul, J., Conversion and In Situ FTIR Studies of Direct NO Decomposition over Cu-ZSM5, Appl. Catal., B 1998, 17, 293-311.

(7) Gao, F.; Kwak, J. H.; Szanyi, J.; Peden, C. H. F., Current Understanding of Cu-Exchanged Chabazite Molecular Sieves for Use as Commercial Diesel Engine DeNOx Catalysts, Top. Catal. 2013, 56, 1441-1459.

(8) Iwasaki, M. In Urea-SCR Technology for deNOx After Treatment of Diesel Exhausts; I. Nova, E. T. E., Ed.; Springer: New York, 2014, p 221-246. 
(9) Liu, Z.; Ihl Woo, S., Recent Advances in Catalytic DeNOx Science and Technology, Catal. Rev. - Sci. Eng. 2006, 48, 43-89.

(10) Palomino, G. T.; Fisicaro, P.; Bordiga, S.; Zecchina, A.; Giamello, E.; Lamberti, C., Oxidation States of Copper Ions in ZSM-5 Zeolites. A Multitechnique Investigation, J. Phys. Chem. B 2000, 104, 4064-4073.

(11) Schoonheydt, R. A., UV-vis-NIR Spectroscopy and Microscopy of Heterogeneous Catalysts, Chem. Soc. Rev. 2010, 39, 5051-5066.

(12) Wang, D.; Zhang, L.; Kamasamudram, K.; Epling, W. S., In Situ-DRIFTS Study of Selective Catalytic Reduction of $\mathrm{NOx}$ by $\mathrm{NH}_{3}$ over Cu-Exchanged SAPO-34, ACS Catal. 2013, 3, 871-881.

(13) Yu, T.; Hao, T.; Fan, D.; Wang, J.; Shen, M.; Li, W., Recent $\mathrm{NH}_{3}-\mathrm{SCR}$ Mechanism Research over Cu/SAPO-34 Catalyst, J. Phys. Chem. C 2014, 118, 6565-6575.

(14) Kwak, J. H.; Tran, D.; Burton, S. D.; Szanyi, J.; Lee, J. H.; Peden, C. H. F., Effects of Hydrothermal Aging on $\mathrm{NH}_{3}$-SCR Reaction over Cu/Zeolites, J. Catal. 2012, 287, 203-209.

(15) Wang, J.; Zhao, H.; Haller, G.; Li, Y., Recent Advances in the Selective Catalytic Reduction of NOx with $\mathrm{NH}_{3}$ on Cu-Chabazite Catalysts, Appl. Catal., B 2017, 202, 346-354.

(16) Borfecchia, E.; Lomachenko, K. A.; Giordanino, F.; Falsig, H.; Beato, P.; Soldatov, A. V.; Bordiga, S.; Lamberti, C., Revisiting the Nature of Cu Sites in the Activated Cu-SSZ-13 Catalyst for SCR Reaction, Chem. Sci. 2015, 6, 548-563.

(17) Paolucci, C.; Khurana, I.; Parekh, A. A.; Li, S.; Shih, A. J.; Li, H.; Di Iorio, J. R.; Albarracin-Caballero, J. D.; Yezerets, A.; Miller, J. T.et al, Dynamic Multinuclear Sites Formed by Mobilized Copper Ions in NOx Selective Catalytic Reduction, Science 2017, 357, 898-903. 
(18) Andersen, C. W.; Bremholm, M.; Vennestrom, P. N. R.; Blichfeld, A. B.; Lundegaard, L. F.; Iversen, B. B., Location of $\mathrm{Cu}^{2+}$ in CHA Zeolite Investigated by X-ray Diffraction Using the Rietveld/Maximum Entropy Method, IUCrJ 2014, 1, 382-386.

(19) Godiksen, A.; Stappen, F. N.; Vennestroem, P. N. R.; Giordanino, F.; Rasmussen, S. B.; Lundegaard, L. F.; Mossin, S., Coordination Environment of Copper Sites in Cu-CHA Zeolite Investigated by Electron Paramagnetic Resonance, J. Phys. Chem. C 2014, 118, 23126-23138. (20) Lomachenko, K. A.; Borfecchia, E.; Negri, C.; Berlier, G.; Lamberti, C.; Beato, P.; Falsig, H.; Bordiga, S., The Cu-CHA deNOx Catalyst in Action: Temperature-Dependent $\mathrm{NH}_{3}$-Assisted Selective Catalytic Reduction Monitored by Operando XAS and XES, J. Am. Chem. Soc. 2016, 138, 12025-12028.

(21) Kwak, J. H.; Tonkyn, R. G.; Kim, D. H.; Szanyi, J.; Peden, C. H. F., Excellent Activity and Selectivity of Cu-SSZ-13 in the Selective Catalytic Reduction of $\mathrm{NOx}$ with $\mathrm{NH}_{3}, J$. Catal. 2010, $275,187-190$.

(22) Moliner, M.; Martinez, C.; Corma, A., Synthesis Strategies for Preparing Useful Small Pore Zeolites and Zeotypes for Gas Separations and Catalysis, Chem. Mater. 2014, 26, 246258.

(23) Zhang, R.; McEwen, J.-S.; Kollár, M.; Gao, F.; Wang, Y.; Szanyi, J.; Peden, C. H. F., NO Chemisorption on Cu/SSZ-13: A Comparative Study from Infrared Spectroscopy and DFT Calculations, ACS Catalysis 2014, 4, 4093-4105.

(24) Zones, S. I.; Chevron Research Co., USA . 1985, p 9 pp. Cont.-in-part of U.S. Ser. No. 397,007, abandoned.

(25) Luo, J.; Gao, F.; Kamasamudram, K.; Currier, N.; Peden, C. H. F.; Yezerets, A., New Insights into $\mathrm{Cu} / \mathrm{SSZ}-13$ SCR Catalyst Acidity. Part I: Nature of Acidic Sites Probed by $\mathrm{NH}_{3}$ Titration, J. Catal. 2017, 348, 291-299. 
(26) Bendrich, M.; Scheuer, A.; Hayes, R. E.; Votsmeier, M., Unified Mechanistic Model for Standard SCR, Fast SCR, and $\mathrm{NO}_{2}$ SCR over a Copper Chabazite Catalyst, Appl. Catal., B 2018, 222, 76-87.

(27) Fickel, D. W.; Fedeyko, J. M.; Lobo, R. F., Copper Coordination in Cu-SSZ-13 and CuSSZ-16 Investigated by Variable-Temperature XRD, J. Phys. Chem. C 2010, 114, 1633-1640. (28) Gao, F.; Walter, E. D.; Karp, E. M.; Luo, J.; Tonkyn, R. G.; Kwak, J. H.; Szanyi, J.; Peden, C. H. F., Structure-Activity Relationships in $\mathrm{NH}_{3}-\mathrm{SCR}$ over Cu-SSZ-13 as Probed by Reaction Kinetics and EPR Studies, J. Catal. 2013, 300, 20-29.

(29) Korhonen, S. T.; Fickel, D. W.; Lobo, R. F.; Weckhuysen, B. M.; Beale, A. M., Isolated $\mathrm{Cu}^{2+}$ Ions: Active Sites for Selective Catalytic Reduction of NO, Chem. Commun. 2011, 47, 800-802.

(30) Kwak, J. H.; Zhu, H.; Lee, J. H.; Peden, C. H. F.; Szanyi, J., Two Different Cationic Positions in Cu-SSZ-13?, Chem. Commun. 2012, 48, 4758-4760.

(31) Deka, U.; Juhin, A.; Eilertsen, E. A.; Emerich, H.; Green, M. A.; Korhonen, S. T.; Weckhuysen, B. M.; Beale, A. M., Confirmation of Isolated $\mathrm{Cu}^{2+}$ Ions in SSZ-13 Zeolite as Active Sites in $\mathrm{NH}_{3}$-Selective Catalytic Reduction, J. Phys. Chem. C 2012, 116, 4809-4818.

(32) Gao, F.; Walter, E. D.; Kollar, M.; Wang, Y.; Szanyi, J.; Peden, C. H. F., Understanding Ammonia Selective Catalytic Reduction Kinetics over $\mathrm{Cu} / \mathrm{SSZ}-13$ from Motion of the $\mathrm{Cu}$ Ions, J. Catal. 2014, 319, 1-14.

(33) Berthomieu, D.; Krishnamurty, S.; Heine, T.; Goursot, A., Molecular Dynamics Simulations of $\mathrm{H}_{2} \mathrm{O}$ with Sites of $\mathrm{Cu}^{\mathrm{I}}-\mathrm{FAU}$ and $\mathrm{Cu}^{\mathrm{II}}-\mathrm{FAU}$, Stud. Surf. Sci. Catal. 2005, 158, 655-662.

(34) Paolucci, C.; Verma, A. A.; Bates, S. A.; Kispersky, V. F.; Miller, J. T.; Gounder, R.; Delgass, W. N.; Ribeiro, F. H.; Schneider, W. F., Isolation of the Copper Redox Steps in the 
Standard Selective Catalytic Reduction on Cu-SSZ-13, Angew. Chem. Int. Ed. 2014, 53, 11828-11833.

(35) Gunter, T.; Carvalho, H. W. P.; Doronkin, D. E.; Sheppard, T.; Glatzel, P.; Atkins, A. J.; Rudolph, J.; Jacob, C. R.; Casapu, M.; Grunwaldt, J.-D., Structural Snapshots of the SCR Reaction Mechanism on Cu-SSZ-13, Chem. Commun. 2015, 51, 9227-9230.

(36) Giordanino, F.; Borfecchia, E.; Lazzarini, A.; Bordiga, S.; Lomachenko, K. A.; Soldatov, A. V.; Lamberti, C.; Agostini, G.; Gallo, E.; Beato, P., Interaction of $\mathrm{NH}_{3}$ with Cu-SSZ-13 Catalyst: A Complementary FTIR, XANES, and XES Study, J. Phys. Chem. Lett. 2014, 5, $1552-1559$.

(37) McEwen, J. S.; Anggara, T.; Schneider, W. F.; Kispersky, V. F.; Miller, J. T.; Delgass, W. N.; Ribeiro, F. H., Integrated Operando X-Ray Absorption and DFT Characterization of $\mathrm{Cu}-\mathrm{SSZ}-13$ Exchange Sites during the Selective Catalytic Reduction of $\mathrm{NOx}$ with $\mathrm{NH}_{3}$, Catal. Today 2012, 184, 129-144.

(38) Schneider, W. F.; Hass, K. C.; Ramprasad, R.; Adams, J. B., Density Functional Theory Study of Transformations of Nitrogen Oxides Catalyzed by Cu-Exchanged Zeolites, J. Phys. Chem. B 1998, 102, 3692-3705.

(39) Mao, Y.; Wang, H.-F.; Hu, P., Theoretical Investigation of $\mathrm{NH}_{3}-\mathrm{SCR}$ Processes over Zeolites: A Review, Int. J. Quantum Chem. 2015, 115, 618-630.

(40) Crandell, D. W.; Zhu, H.; Yang, X.; Hochmuth, J.; Baik, M.-H., Computational and Spectroscopic Characterization of Key Intermediates of the Selective Catalytic Reduction Cycle of NO on Zeolite-Supported Cu Catalyst, Inorg. Chim. Acta 2015, 430, 132-143.

(41) Berthomieu, D.; Delahay, G., Recent Advances in $\mathrm{Cu}^{\mathrm{I} / \mathrm{II}} \mathrm{Y}$ : Experiments and Modeling, Catal. Rev. 2006, 48, 269-313.

(42) Bates, S. A.; Verma, A. A.; Paolucci, C.; Parekh, A. A.; Anggara, T.; Yezerets, A.; Schneider, W. F.; Miller, J. T.; Delgass, W. N.; Ribeiro, F. H., Identification of the Active Cu 
site in Standard Selective Catalytic Reduction with Ammonia on Cu-SSZ-13, J. Catal. 2014, $312,87-97$.

(43) Paolucci, C.; Parekh, A. A.; Khurana, I.; Di Iorio, J. R.; Li, H.; Albarracin Caballero, J. D.; Shih, A. J.; Anggara, T.; Delgass, W. N.; Miller, J. T.et al, Catalysis in a Cage: ConditionDependent Speciation and Dynamics of Exchanged Cu Cations in SSZ-13 Zeolites, J. Am. Chem. Soc. 2016, 138, 6028-6048.

(44) Göltl, F.; Bulo, R. E.; Hafner, J.; Sautet, P., What Makes Copper-Exchanged SSZ-13 Zeolite Efficient at Cleaning Car Exhaust Gases?, J. Phys. Chem. Lett. 2013, 4, 2244-2249.

(45) Göltl, F.; Sautet, P.; Hermans, I., The Impact of Finite Temperature on the Coordination of Cu Cations in the Zeolite SSZ-13, Catal. Today 2016, 267, 41-46.

(46) Göltl, F.; Love, A. M.; Hermans, I., Developing a Thermodynamic Model for the Interactions between Water and $\mathrm{Cu}$ in the Zeolite SSZ-13, J. Phys. Chem. C 2017, 121, 61606169.

(47) Janssens, T. V. W.; Falsig, H.; Lundegaard, L. F.; Vennestrøm, P. N. R.; Rasmussen, S. B.; Moses, P. G.; Giordanino, F.; Borfecchia, E.; Lomachenko, K. A.; Lamberti, C.et al, A Consistent Reaction Scheme for the Selective Catalytic Reduction of Nitrogen Oxides with Ammonia, ACS Catalysis 2015, 5, 2832-2845.

(48) Siahrostami, S.; Falsig, H.; Beato, P.; Moses, P. G.; Nørskov, J. K.; Studt, F., Exploring Scaling Relations for Chemisorption Energies on Transition-Metal-Exchanged Zeolites ZSM22 and ZSM-5, ChemCatChem 2016, 8, 767-772.

(49) Lezcano-Gonzalez, I.; Deka, U.; Arstad, B.; Van Yperen-De Deyne, A.; Hemelsoet, K.; Waroquier, M.; Van Speybroeck, V.; Weckhuysen, B. M.; Beale, A. M., Determining the Storage, Availability and Reactivity of $\mathrm{NH}_{3}$ within $\mathrm{Cu}$-Chabazite-Based Ammonia Selective Catalytic Reduction Systems, Phys. Chem. Chem. Phys. 2014, 16, 1639-1650. 
(50) Moreno-González, M.; Hueso, B.; Boronat, M.; Blasco, T.; Corma, A., AmmoniaContaining Species Formed in Cu-Chabazite As Per In Situ EPR, Solid-State NMR, and DFT Calculations, J. Phys. Chem. Lett. 2015, 6, 1011-1017.

(51) Concepción, P.; Boronat, M.; Millán, R.; Moliner, M.; Corma, A., Identification of Distinct Copper Species in Cu-CHA Samples Using NO as Probe Molecule. A Combined IR Spectroscopic and DFT Study, Topics Catal. 2017, 60, 1653-1663.

(52) Grunwaldt, J. D.; Caravati, M.; Hannemann, S.; Baiker, A., X-Ray Absorption Spectroscopy under Reaction Conditions: Suitability of Different Reaction Cells for Combined Catalyst Characterization and Time-Resolved Studies, Phys. Chem. Chem. Phys. 2004, 6, 3037-3047.

(53) Doronkin, D. E.; Baier, S.; Sheppard, T.; Benzi, F.; Grunwaldt, J. D., Lithographically Fabricated Silicon Microreactor for Operando QEXAFS Studies in Exhaust Gas Catalysis during Simulation of a Standard Driving Cycle, J. Phys.: Conf. Ser. 2016, 712, 012030.

(54) Kresse, G.; Hafner, J., Ab Initio Molecular-Dynamics Simulation of the Liquid-MetalAmorphous-Semiconductor Transition in Germanium, Phys. Rev. B 1994, 49, 14251-14269.

(55) Kresse, G.; Furthmüller, J., Efficiency of Ab-Initio Total Energy Calculations for Metals and Semiconductors using a Plane-Wave Basis Set, Comput. Mat. Sci. 1996, 6, 15-50.

(56) Perdew, J.; Burke, K.; Ernzerhof, M., Generalized Gradient Approximation Made Simple, Phys. Rev. Lett. 1996, 77, 3865-3868.

(57) Kresse, G.; Joubert, D., From Ultrasoft Pseudopotentials to the Projector AugmentedWave Method, Phys. Rev. B 1999, 59, 1758-1775.

(58) Grimme, S., Semiempirical GGA-Type Density Functional Constructed with a LongRange Dispersion Correction, J. Comput. Chem. 2006, 27, 1787-1799.

(59) Klimes, J.; Bowler, D. R.; Michaelides, A., Chemical Accuracy for the van der Waals Density Functional, J. Phys.: Condens. Matter 2010, 22, 022201. 
(60) Sanville, E.; Kenny, S. D.; Smith, R.; Henkelman, G., Improved Grid-Based Algorithm for Bader Charge Allocation, J. Comput. Chem. 2007, 28, 899-908.

(61) Henkelman, G.; Arnaldsson, A.; Jonsson, H., A Fast and Robust Algorithm for Bader Decomposition of Charge Density, Comput. Mat. Sci. 2006, 36, 354-360.

(62) Baerlocher, C.; McCusker, J. K., Database of Zeolite Structures: http://www.izastructure.org/databases/.

(63) Mager-Maury, C.; Bonnard, G.; Chizallet, C.; Sautet, P.; Raybaud, P., $\mathrm{H}_{2}$-induced reconstruction of supported Pt clusters: metal-support interaction versus surface hydride, ChemCatChem 2011, 3, 200-207.

(64) Futschek, T.; Marsman, M.; Hafner, J., Structural and magnetic isomers of small Pd and Rh clusters: an ab initio density functional study, J. Phys.: Condens. Matter 2005, 17, 59275963.

(65) Rey, J.; Raybaud, P.; Chizallet, C., Ab Initio Simulation of the Acid Sites at the External Surface of Zeolite Beta, ChemCatChem 2017, 9, 2176-2185.

(66) Larmier, K.; Nicolle, A.; Chizallet, C.; Cadran, N.; Maury, S.; Lamic-Humblot, A.-F.; Marceau, E.; Lauron-Pernot, H., Influence of Coadsorbed Water and Alcohol Molecules on Isopropyl Alcohol Dehydration on $\gamma$-Alumina: Multiscale Modeling of Experimental Kinetic Profile, ACS Catalysis 2016, 6, 1905-1920.

(67) Frahm, R.; Nachtegaal, M.; Stötzel, J.; Harfouche, M.; van Bokhoven, J. A.; Grunwaldt, J. D., The dedicated QEXAFS facility at the SLS: Performance and Scientific Opportunities, AIP Conf. Proc. 2010, 1234, 251-255.

(68) Ravel, B.; Newville, M., ATHENA, ARTEMIS, HEPHAESTUS: Data Analysis for XRay Absorption Spectroscopy using IFEFFIT, J. Synchrotron Rad. 2005, 12, 537-541.

(69) de Juan, A.; Jaumot, J.; Tauler, R., Multivariate Curve Resolution (MCR). Solving the Mixture Analysis Problem, Anal. Methods 2014, 6, 4964-4976. 
(70) Jaumot, J.; de Juan, A.; Tauler, R., MCR-ALS GUI 2.0: New Features and Applications, Chemom. Intell. Lab. Syst. 2015, 140, 1-12.

(71) Lamberti, C.; Bordiga, S.; Bonino, F.; Prestipino, C.; Berlier, G.; Capello, L.; D'Acapito, F.; Llabres i Xamena, F. X.; Zecchina, A., Determination of the Oxidation and Coordination State of Copper on Different Cu-Based Catalysts by XANES Spectroscopy In Situ or In Operando Conditions, Phys. Chem. Chem. Phys. 2003, 5, 4502-4509.

(72) Rehr, J. J.; Albers, R. C., Theoretical Approaches to X-Ray Absorption Fine Structure, Rev. Mod. Phys. 2000, 72, 621-654.

(73) Pavelka, M.; Burda, J. V., Theoretical Description of Copper $\mathrm{Cu}(\mathrm{I}) / \mathrm{Cu}(\mathrm{II})$ Complexes in Mixed Ammine-Aqua Environment. DFT and Ab Initio Quantum Chemical Study, Chem. Phys. 2005, 312, 193-204.

(74) Berthomieu, D.; Krishnamurty, S.; Coq, B.; Delahay, G.; Goursot, A., Theoretical Modeling of a Copper Site in a Cu(II)-Y Zeolite, J. Phys. Chem. B 2001, 105, 1149-1156.

(75) Li, H.; Paolucci, C.; Schneider, W. F., Zeolite Adsorption Free Energies from ab Initio Potentials of Mean Force, J. Chem. Theory Comput. 2018, 14, 929-938.

(76) Chen, L.; Falsig, H.; Janssens, T. V. W.; Grönbeck, H., Activation of oxygen on $\left(\mathrm{NH}_{3^{-}}\right.$ $\left.\mathrm{Cu}-\mathrm{NH}_{3}\right)^{+}$in $\mathrm{NH}_{3}-\mathrm{SCR}$ over Cu-CHA, J. Catal. 2018, 358, 179-186.

(77) Yamashita, H.; Matsuoka, M.; Tsuji, K.; Shioya, Y.; Anpo, M.; Che, M., In-Situ XAFS, Photoluminescence, and IR Investigations of Copper Ions Included within Various Kinds of Zeolites. Structure of $\mathrm{Cu}(\mathrm{I})$ Ions and Their Interaction with $\mathrm{CO}$ Molecules, J. Phys. Chem. 1996, 100, 397-402.

(78) Kau, L. S.; Spira-Solomon, D. J.; Penner-Hahn, J. E.; Hodgson, K. O.; Solomon, E. I., XRay Absorption Edge Determination of the Oxidation State and Coordination Number of Copper. Application to the Type 3 Site in Rhus Vernicifera Laccase and its Reaction with Oxygen, J. Am. Chem. Soc. 1987, 109, 6433-6442. 
TOC graphic

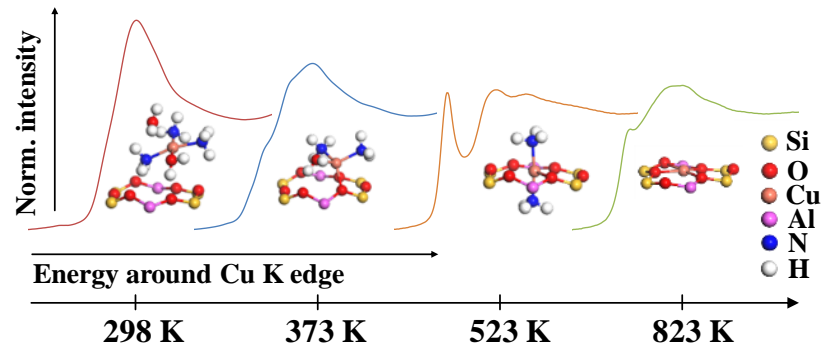

